University of Nebraska - Lincoln

DigitalCommons@University of Nebraska - Lincoln

\title{
Chronostratigraphic significance of cathodoluminescence zoning in syntaxial cement: Mississippian Lake Valley Formation, New Mexico
}

Tracy D. Frank

University of Nebraska-Lincoln, tfrank2@unl.edu

Kuger C. Lohmann

University of Michigan

William J. Meyers

State University of New York at Stony Brook

Follow this and additional works at: https://digitalcommons.unl.edu/geosciencefacpub

Part of the Earth Sciences Commons

Frank, Tracy D.; Lohmann, Kuger C.; and Meyers, William J., "Chronostratigraphic significance of cathodoluminescence zoning in syntaxial cement: Mississippian Lake Valley Formation, New Mexico" (1995). Papers in the Earth and Atmospheric Sciences. 114.

https://digitalcommons.unl.edu/geosciencefacpub/114

This Article is brought to you for free and open access by the Earth and Atmospheric Sciences, Department of at DigitalCommons@University of Nebraska - Lincoln. It has been accepted for inclusion in Papers in the Earth and Atmospheric Sciences by an authorized administrator of DigitalCommons@University of Nebraska - Lincoln. 


\title{
Chronostratigraphic significance of
}

\section{cathodoluminescence zoning in syntaxial cement: Mississippian Lake Valley Formation, New Mexico}

\author{
Tracy D. Frank, ${ }^{1}$ Kyger C Lohmann, ${ }^{1}$ and William J. Meyers ${ }^{2}$ \\ 1. Department of Geological Sciences, University of Michigan, Ann Arbor, MI 48109-1063, USA \\ 2. Department of Earth and Space Sciences, State University of New York at Stony Brook, \\ Stony Brook, NY 11794-2100, USA
}

\begin{abstract}
Echinoderm-syntaxial cement crystals have been collected at several stratigraphic levels within the Lake Valley Formation, which is overlain by a major pre-Pennsylvanian subaerial exposure surface. The crystals were microsampled along growth bands, and yielded high-resolution elemental and isotopic information that record fluid evolution during their growth. Although cement crystals show little variation in cathodoluminescence character and bulk chemistry throughout the regional extent of the formation, intracrystalline patterns in minor element and stable isotope chemistry allow for the identification of several settings of cementation, including the marine phreatic, marine-meteoric mixing, and meteoric phreatic zones. When placed in a regionalstratigraphic context, crystal growth records enable reconstruction of the temporal and spatial extent of these diagenetic environments.

Isotopic, petrographic and stratigraphic constraints indicate that cementation was related to two temporally distinct meteoric systems. Most Lake Valley Formation syntaxial cement formed in the marine phreatic and marine-meteoric mixing zones during the earliest phase of cementation. Of this cement, in excess of $60 \%$ formed in the marine phreatic zone and lowermost marine-meteoric mixing zone. Smaller volumes precipitated from progressively fresher mixtures of marine and meteoric fluid during the gradual expansion of a freshwater lens that developed in response to pre-Pennsylvanian lowering of sea level. Meteoric phreatic fluids were relatively unimportant during this episode of cementation. In contrast, cement of entirely meteoric phreatic origin is associated with a later meteoric system, but is found only in the northern part of the study area and at stratigraphic levels immediately adjacent to the pre-Pennsylvanian unconformity. Our results indicate that cements in the upper and lower parts of the Lake Valley Formation are genetically and temporally unrelated. Thus, the cement cathodoluminescence stratigraphy, which has been previously applied to the Lake Valley, can not be valid over the full extent of the formation. This has wider implications. Our demonstration that diverse and temporally distinct diagenetic settings can produce identical CL characteristics shows that caution should be employed when using cement CL stratigraphy alone to extend diagenetic interpretations over large geographic regions or through substantial stratigraphic successions.
\end{abstract}




\section{Introduction}

One of the major concepts arising from diagenetic studies of carbonate sequences is that waterrock interaction in meteoric phreatic zones is a major process that influences the composition of pore waters and early carbonate cements (e.g., Friedman, 1964; Matthews, 1968; Land, 1970; Steinen and Matthews, 1973; James and Choquette, 1990). Models of meteoric diagenesis that resulted from such investigations are based primarily on observations in Quaternary settings for which both pore water chemistry and exposure history are often known (e.g., Harris and Matthews, 1968; Budd, 1988). The advent of cathodoluminescence (CL) cement stratigraphy (Meyers, 1974) allowed such Quaternary-based models to be applied to regional diagenetic patterns in ancient pericontinental and epicontinental carbonate sequences (e.g., Wagner and Matthews, 1982; Kaufman et al., 1988; Niemann and Read, 1988). However, because most Quaternary deposits differ markedly from their ancient counterparts in terms of regional extent, exposure history, and original mineralogy (e.g., Wilkinson, 1979; James and Bone, 1989), it is important that diagenetic patterns in ancient carbonate successions be independently and quantitatively studied to evaluate the applicability of diagenetic models derived from Quaternary sequences (e.g., Budd et al., 1993).

Because the chemical composition of diagenetic phases reflects the chemistry of fluids from which they precipitate, intergranular cement provides a unique means by which processes of diagenesis in ancient carbonate sequences can be examined. This paper presents the results of a regional stratigraphic study of micrometer-scale geochemical heterogeneities among successive CL zones within individual cement crystals from the Mississippian Lake Valley Formation of southern New Mexico. The purpose of this investigation was to evaluate: (1) the origin and relative importance of diagenetic fluids from which cement precipitated; (2) the temporal and spatial evolution in pore water composition during cementation; (3) the chronostratigraphic significance of CL cement stratigraphy; and (4) the applicability of Quaternary diagenetic models to ancient epicontinental carbonate strata. The Lake Valley Formation was specifi- cally chosen for examination, because this classic sequence serves as the reference model and locality for validation of CL cement stratigraphic concepts, and for recognizing and interpreting meteoric diagenetic alteration in many ancient carbonate sequences (e.g., Grover and Read, 1983; Dorobek, 1987; Goldstein, 1988; Kaufman et al., 1988).

\section{Geologic setting}

The stratigraphic and petrographic framework of the Lake Valley Formation is well described through early work (e.g., Laudon and Bowsher, 1941; Pray, 1961), and through an exhaustive series of diagenetic studies (e.g., Meyers, 1974, 1978; Meyers and James, 1978; Meyers and Lohmann, 1985). This wealth of prior research makes the Lake Valley Formation an ideal setting in which to study spatial and temporal patterns of early diagenesis.

\subsection{Stratigraphic framework}

The Osagean Lake Valley Formation (Figure 1) is well exposed along the western escarpment of the Sacramento Mountains, New Mexico, where it reaches a maximum thickness of about $120 \mathrm{~m}$ (Pray, 1961). Throughout this region, it unconformably overlies the Kinderhookian Caballero Formation. In the southern part of the Sacramento Mountains it is separated from the overlying Meramecian Rancheria Formation by an erosional unconformity that shows local angular truncation, while to the north it is separated from the Morrowan Gobbler Formation by a major pre-Pennsylvanian unconformity that extends throughout the study area (Meyers, 1974).

The Lake Valley Formation is interpreted as an entirely subtidal transgressive-regressive depositional sequence (Pray, 1961; Meyers, 1978). The lowermost interval, the Andrecito Member, consists of echinoderm-bryozoan wackestones and packstones, which are overlain by deeper-water lime mudstones of the Alamogordo Member. These are overlain by argillaceous echinoderm-bryozoan wackestonepackstones of the Nunn Member, which represent a transition into progressively shallower-water echinoderm-bryozoan packstones and grainstones of 


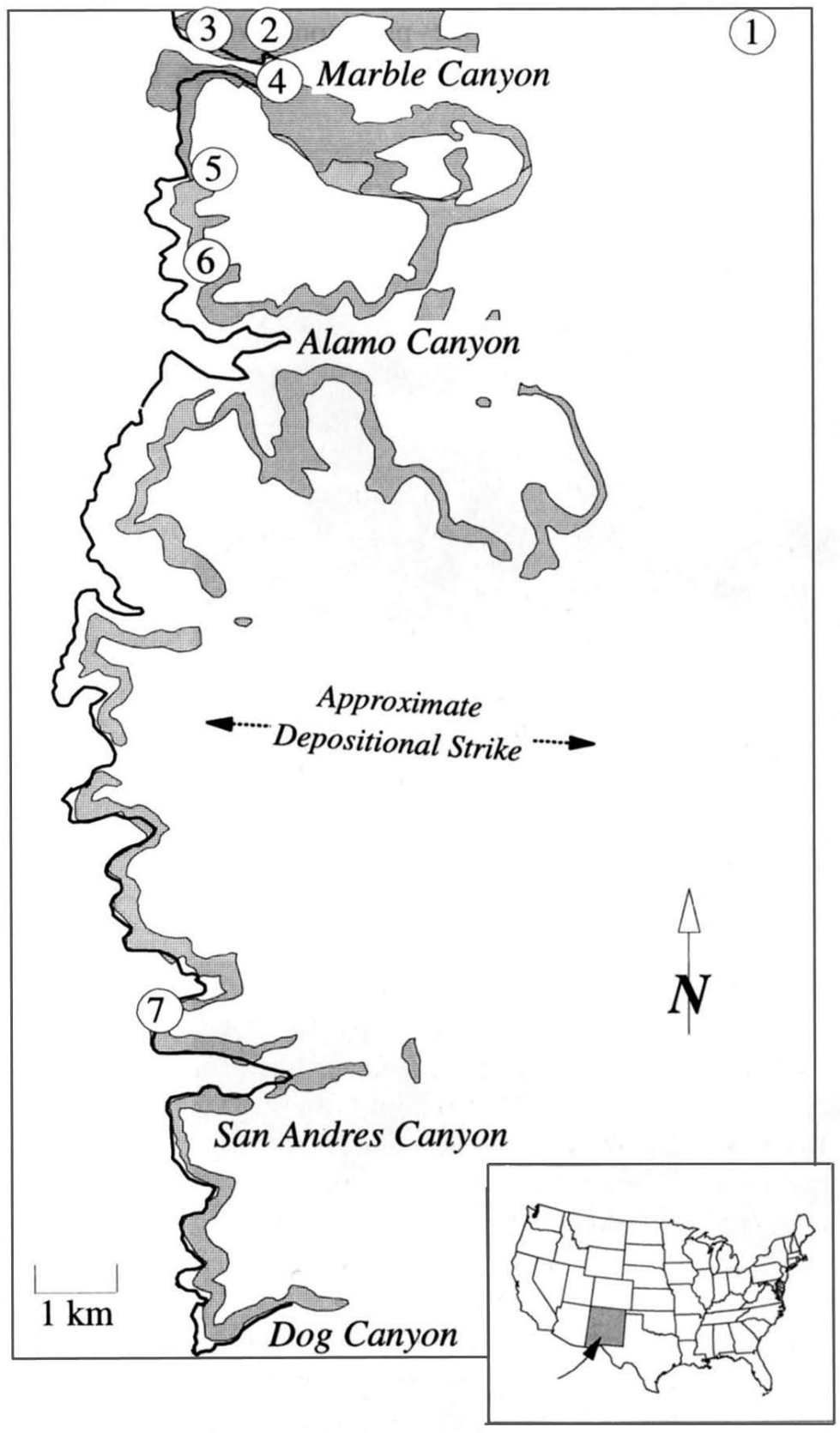

Lake Valley Formation

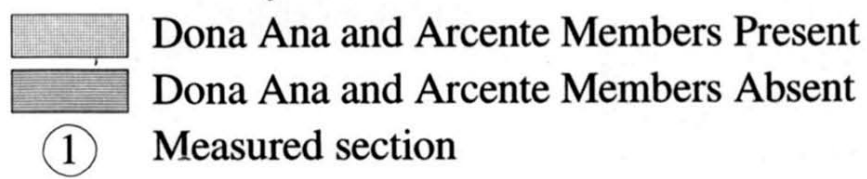

$-5000^{\prime}$ contour
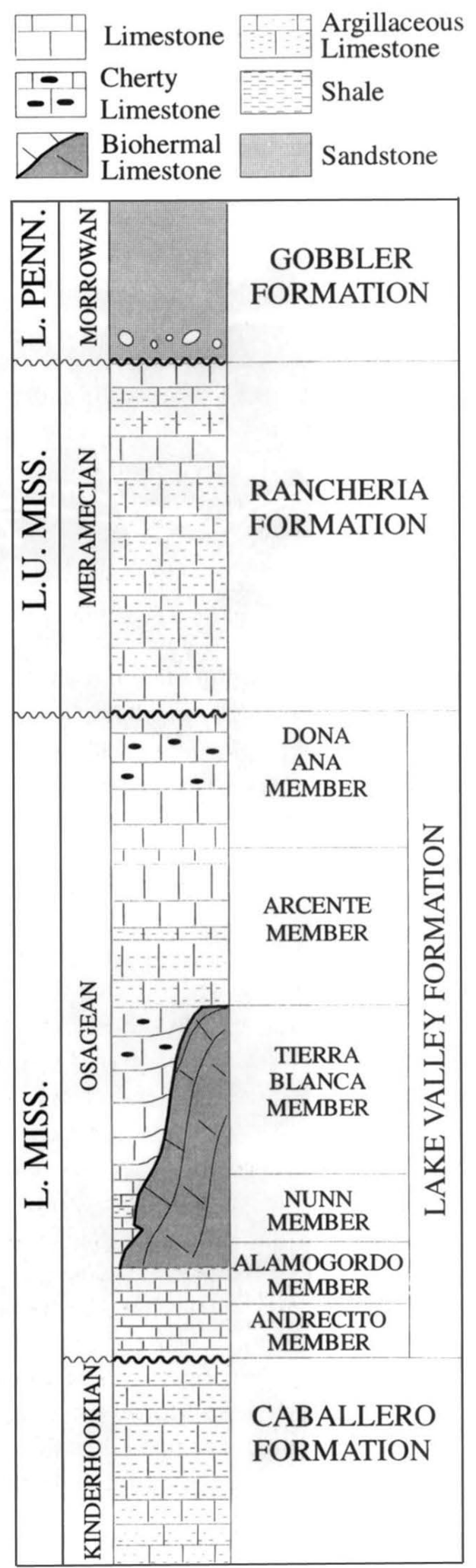

Figure 1. Geologic map showing locations of measured sections (1 to 7) in the Lake Valley Formation in the Sacramento Mountains, south central New Mexico (left), and stratigraphic column (right) of Kinderhookian to Morrowan rocks exposed in the study area (after Pray, 1961). Note the location of the major pre-Pennsylvanian unconformity that is present throughout the region. 
the Tierra Blanca Member. The Tierra Blanca Member accumulated during basinward progradation of subtidal echinoderm shelf sands, and thins to the south where it is overlain by a deeper-water mudstone-packstone couplet comprising the Arcente and Dona Ana Members (Meyers, 1974). This se-
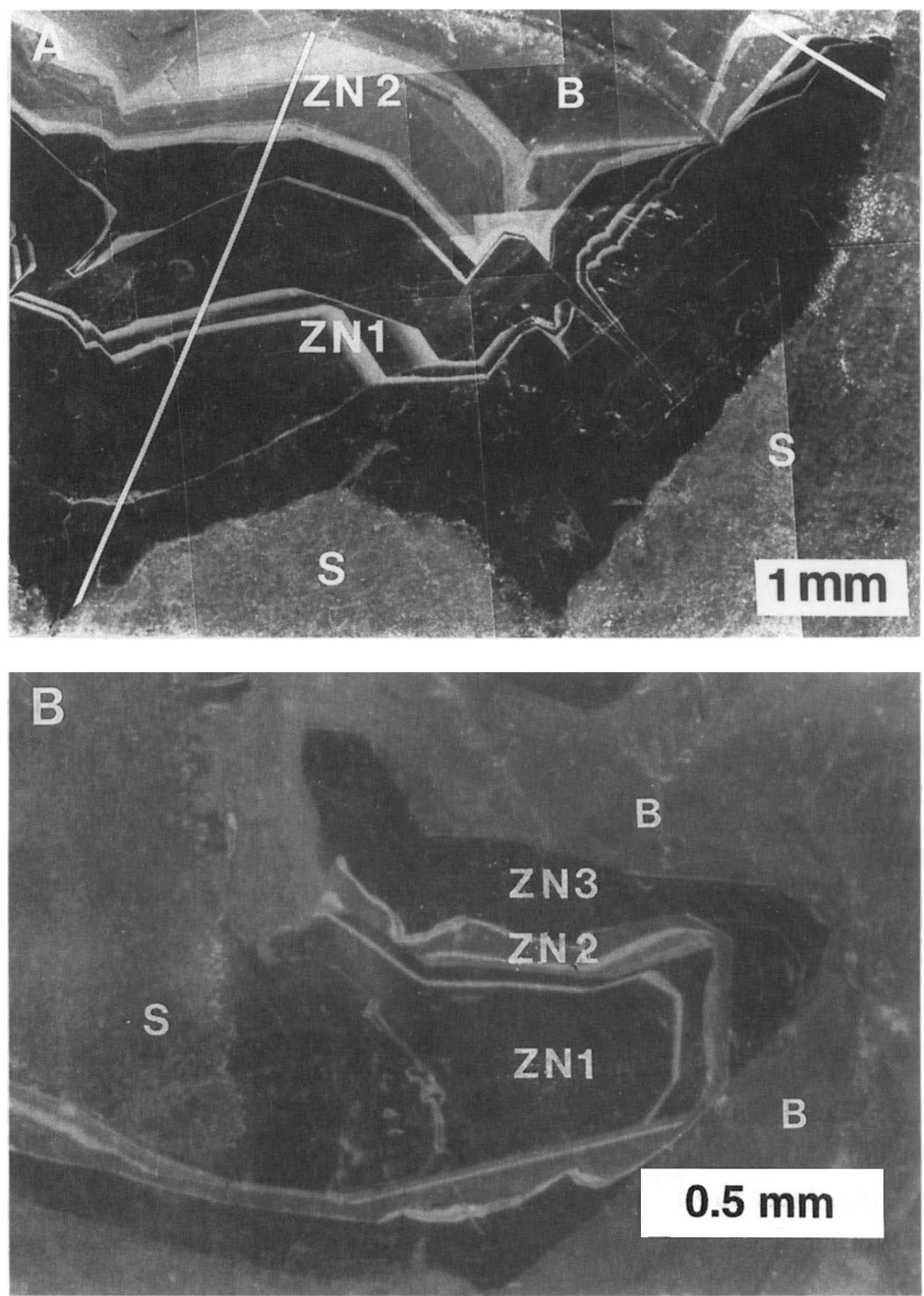

Figure 2. Cathodoluminescence photomicrographs of zoned, echinoderm-syntaxial cements on crinoidal substrate $(S)$ and overlain by dully luminescent, ferroan burial cement (B). (A) Crystal from the base of Section 4 containing Zone 1 (ZN1; generally nonluminescent with thin luminescent bands) and Zone 2 (ZN2; luminescent with bright and dull luminescent subzones). White lines delineate microsampled area of crystal. (B) Cement crystal from near the top of Section 3 containing Zone 1, Zone 2, and Zone 3 (nonluminescent with thin luminescent bands). Note difference in crystal thickness between (A) and (B). 
quence is punctuated by small ( $45 \mathrm{~m}$ thick) bioherms in the northern part of the area, and by large (110 m thick) off-shelf bioherms to the south. Biohermal complexes are made up of massive, echinoderm-bryozoan mudstone and wackestone core facies that grade laterally into steeply inclined echinoderm grainstone flank beds. Bioherm growth began during deposition of the Alamogordo Member and ceased prior to the deposition of the Arcente Member (Pray, 1958). The absence of intraformational marine hardgrounds and subaerial exposure surfaces suggests a relatively simple diagenetic history, in that the Lake Valley Formation was apparently not permeated by multiple freshwater lenses associated with high-frequency changes of sea level or episodes of shoreline migration (Meyers, 1978).

\subsection{Petrographic framework}

Clear, echinoderm-syntaxial calcite makes up about $85 \%$ of intergranular cement in the Lake Valley Formation (Meyers and Lohmann, 1985), which under cathodoluminescence (CL) contain zones that were named and regionally correlated by Meyers $(1974,1978)$. The distribution of the four dominant CL zones immediately adjacent to pre-Meramecian and pre-Morrowan unconformities suggest that the oldest three are Mississippian, while the youngest is a post-Mississippian burial cement that is not considered in this study (Meyers, 1978; Meyers and Hill, 1983). The three CL zones examined in this study, Zone 1, Zone 2, and Zone 3, are distinguished on the basis of their relative order and lu-

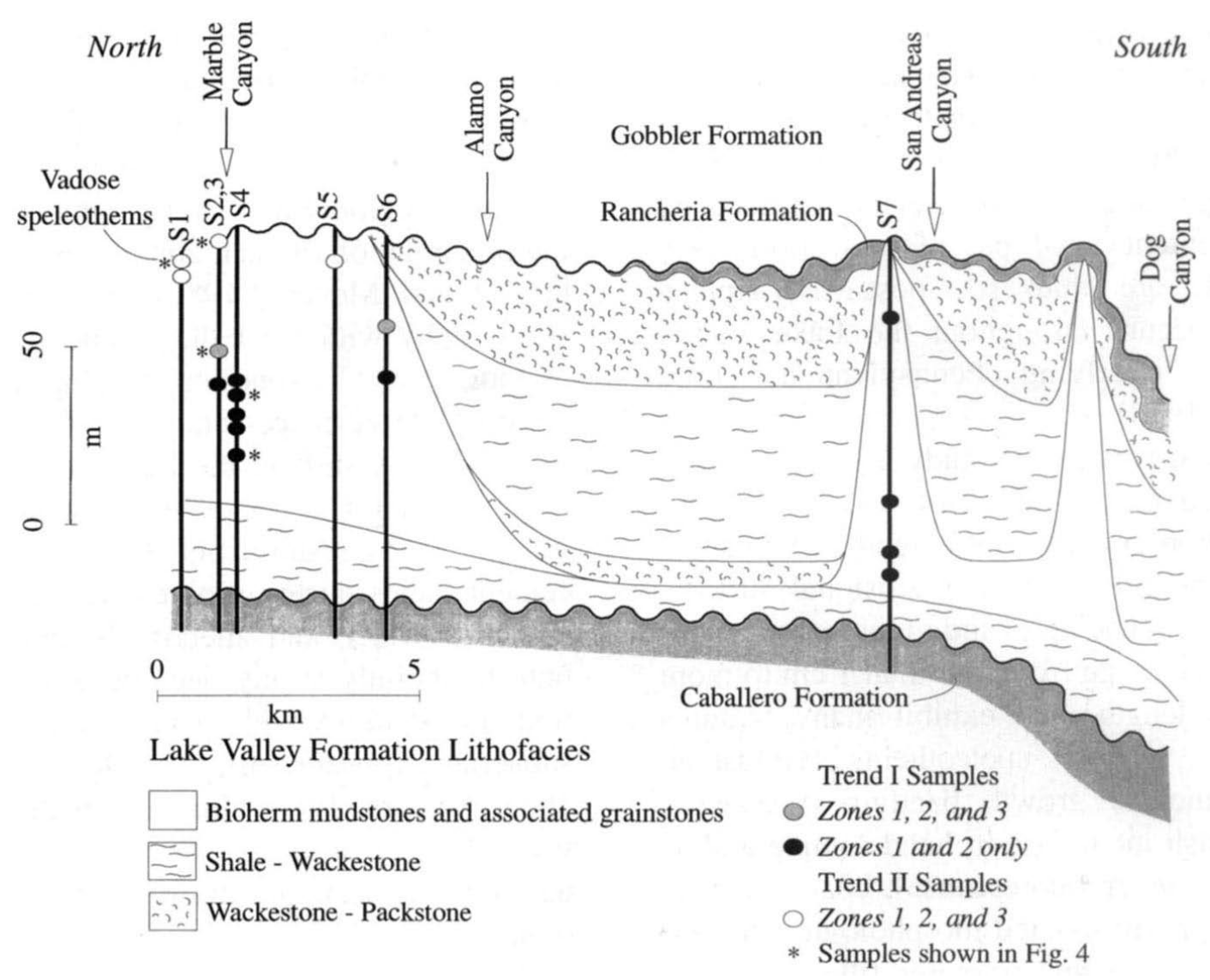

Figure 3. Stratigraphic distribution of cement types along the western part of the Sacramento Mountains as projected along a single north-south cross-section. Note that Trend I cement is volumetrically dominant, while Trend II cement only occurs in the northern part of the field area near the pre-Pennsylvanian exposure surface. Numbered vertical lines indicate positions of measured sections (modified from Meyers, 1974; DeKeyser, 1978). 
minescence characteristics (Figure 2). The earliest zone. Zone 1, is generally nonluminescent, with thin, brightly luminescent subzones. This is overlain by Zone 2, which is luminescent and contains bright and dull luminescent subzones. Zone 3 is nonluminescent, but often contains several thin, luminescent subzones. Regional stratigraphic relations indicate that the maximum pre-Pennsylvanian burial depth at the base of the Lake Valley Formation was $200 \mathrm{~m}$ (Meyers, 1974). Assuming a normal geothermal gradient of $30^{\circ} \mathrm{C} \mathrm{km}^{-1}$, all Mississippian cement precipitated at temperatures less than $30^{\circ} \mathrm{C}$.

Cement zones are not evenly distributed throughout the Lake Valley Formation (Figure 3). The earliest two, Zones 1 and 2, occur throughout the sequence (Meyers, 1974, 1978). Cement crystals containing just these zones make up the volumetric bulk of Mississippian cement, and commonly attain thicknesses in excess of $3 \mathrm{~mm}$ in the lower part of the stratigraphic section. Crystals containing Zones 1, 2, and 3, which occur only in the northern part of the study area and at stratigraphic levels immediately adjacent to the pre-Pennsylvanian unconformity (Meyers, 1974, 1978), are volumetrically less important, and attain thicknesses no greater than $1 \mathrm{~mm}$. Except where porespace is completely occluded by Mississippian cement (lower part of the section where cement crystals are thickest), post-Mississippian burial cement occurs throughout the Lake Valley Formation and overlying Pennsylvanian strata (Meyers, 1974, 1978).

In the northern part of the study area (Section 1, Figs. 1, 3), large masses of coarse calcite spar are present in solution cavities that extend downward 2 to 3 $\mathrm{m}$ from the pre-Morrowan erosional surface. These aggregates, made up of individual prismatic to columnar crystals, range from less than $1 \mathrm{~cm}$ to more than $10 \mathrm{~cm}$ in length, and exhibit many features characteristic of vadose speleothems (Goldstein, 1990). These include growth banding (visible as bands of brownish inclusions in hand sample and as fine laminations under fluorescence), coarse detrital inclusions, and gravity-related morphologic features. Cross-cutting stylolites and fractures filled with ferroan calcite, twinning of calcite in some specimens, and petrographic and microthermometric data from primary fluid inclusions led Goldstein (1990) to interpret these coarse calcites as speleothems that formed in response to pre-Morrowan subaerial exposure and karstification of the Lake Valley Formation.

Throughout the Lake Valley Formation, crinoid columnals are encased in low-magnesium calcite syntaxial cement. Under CL, columnals together with infilling cement show a characteristic blotchy, nonuniform luminescence, resulting from the intergrowth of luminescent and nonluminescent secondary cement with neomorphosed skeletal calcite (Lohmann and Meyers, 1977; Leutloff and Meyers, 1984). Prismatic calcite, interpreted as former fibrous high-magnesium calcite marine cement (Lohmann and Meyers, 1977), are restricted to bioherm facies. Petrographic relations demonstrate that these are syndepositional, and predate precipitation of echinoderm-syntaxial cement.

\section{Previous work}

On the basis of the petrographic characteristics and stratigraphic distribution of CL zones in the Lake Valley Formation, Meyers $(1974,1978)$ developed the concept of CL cement stratigraphy, and proposed regional and stratigraphic synchroneity for the precipitation of each zone. Meyers and Lohmann (1985) and Meyers (1989) integrated this cement stratigraphy with the bulk geochemical composition of individual CL zones to develop a model for the regional meteoric cementation of the Lake Valley Formation. A shift in the bulk isotopic composition of individual CL zones with decreasing age was interpreted to result from the migration of coeval cement facies during progressive exchange between meteoric water and metastable marine carbonate, both temporally at any one site of cement precipitation, and spatially with respect to the distance below subaerial exposure surfaces (Meyers and Lohmann, 1985; Meyers, 1989). Implicit in this interpretation was the acceptance that the CL character of individual zones is a unique discriminator for intercorrelation.

The sample suite used by Meyers and Lohmann (1985) and Meyers (1989), however, represents only that part of the Lake Valley Formation exposed in the northern part of the Sacramento Mountains and at stratigraphic levels immediately adja- 
cent to the pre-Pennsylvanian unconformity. These samples were chosen because cement at this stratigraphic level contains all of the CL zones that were named and correlated by Meyers $(1974,1978)$. Thus, the stratigraphic range was restricted, and results do not necessarily reflect the chemistry of cement present at lower stratigraphic levels. In this context, strongly covariant patterns in $\delta^{18} \mathrm{O}$ and $\delta^{13} \mathrm{C}$ found in cement crystals from the lower part of the Lake Valley Formation, which are not compatible with the meteoric phreatic origin for cement proposed earlier (Meyers and Lohmann, 1985), led Frank and Lohmann (1995) to suggest that the marine-meteoric mixing zone was an important diagenetic environment during cementation.

This investigation builds on previous studies by documenting the geochemical characteristics and spatial distributions of cement CL zones in the context of a regional stratigraphic framework, which is defined on the basis of samples collected from seven measured sections (Figures 1 \& 3). In so doing, we determine the spatial and temporal distribution of various diagenetic environments in the Lake Valley Formation, and evaluate the utility of using cement CL characteristics as unique discriminator for intercorrelation.

\section{Methods}

\subsection{Microsampling}

One unique aspect of this study lies in the scale at which echinoderm-syntaxial cements were sampled, and the small mass of calcite that was analyzed. C, O samples represent no more than 15-20 $\mu \mathrm{g}$ of calcite, typically equivalent to $30-50 \mu \mathrm{m}$ of cement crystal thickness. Because sampling resolution increases with increasing crystal size, field sampling focused on coarse echinoderm grainstones from bioherm flank beds where the thickness of cement crystals (0.5 to 3.0 $\mathrm{mm}$ ) was optimum.

Microsamples were collected from polished sections cut to a thickness of $150 \mu \mathrm{m}$. The growth structure of each cement crystal was determined from CL zoning, and digitally mapped from CL photomicrographs. Multiple contiguous drilling paths parallel to concentric zonation were then constructed using a computer interpolation/contouring program (Frank and Lohmann, 1995; Figure 3). Carbonate microsamples were sequentially milled to a depth of 75-100 $\mu \mathrm{m}$, using a computer-controlled microsampler and faceted drill bit with a $20 \mu \mathrm{m}$ diameter point. Path width varied from 0 to a maximum of $50 \mu \mathrm{m}$ to coincide with lateral change in the width of CL growth zones. All sample paths were milled using the beveled edge of the drill bit rather than the tip, which allowed for the milling of paths (or portions thereof) with widths less than $20 \mu \mathrm{m}$. To insure that samples were accurately collected and that CL zones were not inclined with respect to drill troughs, drill trough bottoms were then examined under CL and compared to CL photomicrographs. Echinoderm grains and vadose flowstone were sampled using a microscopemounted drill assembly with a $500 \mu \mathrm{m}$ diameter dental burr.

\subsection{Isotopic analysis}

Samples were roasted under vacuum at $380^{\circ} \mathrm{C}$ for one hour to remove volatile contaminants and then reacted at $73^{\circ} \mathrm{C}$ with anhydrous phosphoric acid in individual reaction vessels of an on-line, automated Kiel device coupled to a Finnigan-MAT 251 mass spectrometer. Oxygen isotopic ratios were corrected for ${ }^{17} \mathrm{O}$ contribution and are reported in per mil relative to the PDB standard. Precision was maintained at a level better than $0.1 \%$ or $\delta^{13} \mathrm{C}$ and $\delta^{18} \mathrm{O}$ values, and was monitored through daily analyses of NBS powdered calcite standards.

\subsection{Elemental analysis}

$\mathrm{Ca}, \mathrm{Mg}$, and $\mathrm{Mn}$ concentrations were determined by electron microprobe analysis (EMPA) prior to microsampling and by inductively coupled plasma atomic emission spectrometry (ICP-AES) on splits of powders used for $\mathrm{C}-\mathrm{O}$ analysis. All electron microprobe analyses were conducted on a Cameca Camebax microprobe with a beam current of $15 \mathrm{nA}$, a spot size of $10 \mu \mathrm{m}$, and an accelerating voltage of $15 \mathrm{kV}$ for $\mathrm{Mg}$ and $\mathrm{Ca}$ and $30 \mathrm{kV}$ for $\mathrm{Mn}$ and Fe. Counting time was $30 \mathrm{~s}$, and analytical precision was monitored through five replicate analyses at each spot. 
Atomic fractions were normalized around six atoms. $\mathrm{C}$ content was calculated by difference, while $\mathrm{O}$ content was calculated by stoichiometry. Raw cation contents were converted to weights of $\mathrm{MeCO}_{3}$, and total weights of $\mathrm{MeCO}_{3}$ species were used to convert to mole $\% \mathrm{MeCO}_{3}$ and/or ppm (where Me is the minor element in question). Detection limits were $180 \mathrm{ppm}$ for $\mathrm{Mg}$ and $250 \mathrm{ppm}$ for $\mathrm{Mn}$.

Because larger crystals from low in the section and from speleothems allowed for greater sampling resolution and the generation of larger samples, minor element contents were additionally determined for these phases by ICP-AES. These data represent average $\mathrm{Ca}, \mathrm{Mg}$, and $\mathrm{Mn}$ concentrations in splits from five to ten successive $\mathrm{C}-\mathrm{O}$ microsamples and in splits of ca. $100 \mu \mathrm{g}$ samples from speleothems. ICP-AES analytical precision, based on gravimetric standards, was $\pm 2.1 \%$ for $\mathrm{Ca}, \pm 2.1 \%$ for $\mathrm{Mg}$, and $\pm 4.2 \%$ for $\mathrm{Mn}$ for echinoderm-syntaxial cements. Analytical precision for vadose speleothems was $\pm 0.6 \%$ for $\mathrm{Ca}, \pm 3.0 \%$ for $\mathrm{Mg}$, and $\pm 1.4 \%$ for $\mathrm{Mn}$. Better precision for speleothem samples was a result of the larger sample size analyzed from these components.

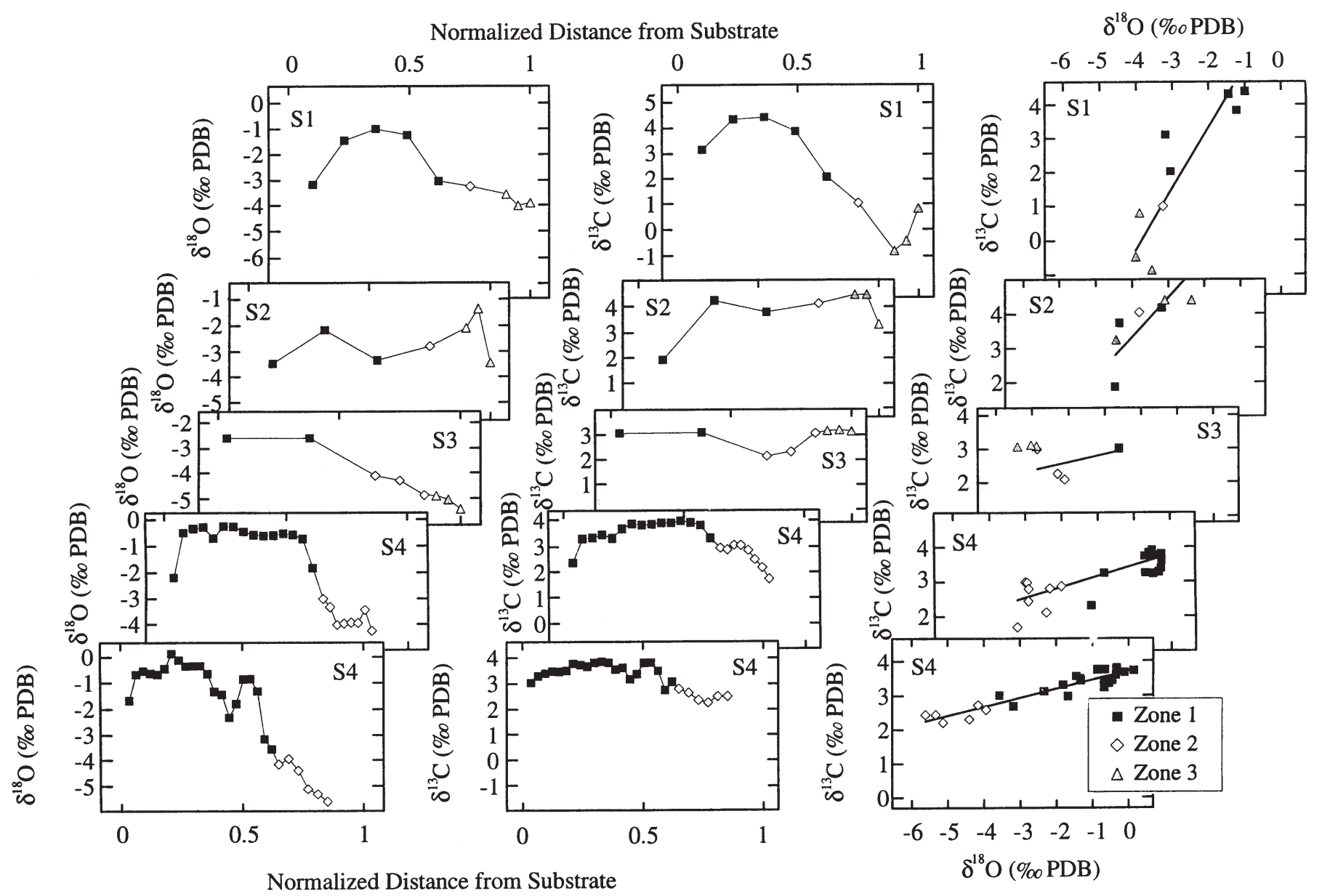

Figure 4. Typical intracrystalline variation in (left part) $\delta^{18} \mathrm{C}$ and (middle part) $\delta^{13} \mathrm{O}$ values of microsamples versus normalized distance from crystal substrates, and (right part) $\delta^{18} \mathrm{O}$ versus $\delta^{13} \mathrm{C}$ values for 5 of 15 crystals analyzed for this study. Boundaries of Zones 1, 2, and 3 were used to normalize positions of microsamples relative to crystal substrates. $\delta^{13} \mathrm{C}$ and $\delta^{18} \mathrm{O}$ values vary with distance from the substrate. These are generally more positive across Zone 1 and become more negative across Zones 2 and 3. Data at the top of the figure (S1) are from a crystal collected at the pre-Pennsylvanian exposure surface, while data from $S 4$ are from crystals collected lower in the stratigraphic section. Note that $\delta^{18} \mathrm{O}$ and $\delta^{13} \mathrm{C}$ values from crystals collected nearer the top of the section covary more steeply than values from crystals collected near the bottom. 


\section{Results}

\subsection{Stable isotopes}

One typical aspect of syntaxial cement is the large variation in isotopic composition within individual crystals. Microsample $\delta^{18} \mathrm{O}$ and $\delta^{13} \mathrm{C}$ values are generally more positive across Zone 1 , and become increasingly negative across Zone 2 and Zone 3 (left and middle part of Figure 4). In addition to spatial change, $\delta^{18} \mathrm{O}$ and $\delta^{13} \mathrm{C}$ values from individual crystals covary (right part of Figure 4). Moreover, the slopes of covariances also vary, such that $\delta^{18} \mathrm{O}$ and $\delta^{13} \mathrm{C}$ values from crystals collected at lower stratigraphic levels and in the southern part of the field area tend to show a shallower slope than do those from crystals that occur in the northern part of the study area and adjacent to the pre-Pennsylvanian unconformity (Figure 4 , right).

When isotopic data from all crystal transects are considered, it becomes apparent that slopes of covariances in $\delta^{13} \mathrm{C}$ and $\delta^{18} \mathrm{O}$ comprise two discrete populations, here referred to as Trend I and Trend II (Figure $5 \mathrm{~A}$, Table 1). $\delta^{18} \mathrm{O}$ and $\delta^{13} \mathrm{C}$ values that lie along Trend I covary strongly $\left(r^{2}=0.89\right)$ with an average slope of 0.36 (Figure 5B). Values that lie along Trend II covary with a steeper average slope of 3.23 (Figure 5B), but have a much lower correlation coefficient than do Trend I data $\left(r^{2}=0.66\right)$. In addition, crystals with Trend I compositions are more variable in oxygen isotope composition $\left(\delta^{18} \mathrm{O}=-2.0 \pm 1.7 \%\right.$ ) , and less variable in carbon isotope composition $\left(\delta^{13} \mathrm{C}=\right.$ $+3.3 \pm 0.7 \%$ o $)$ than are crystals in Trend II $\left(\delta^{18} \mathrm{O}=\right.$ $2.9 \pm 0.8 \%$; $\delta^{13} \mathrm{C}=+2.0 \pm 1.7 \%$ o). Besides these differences, $\delta^{18} \mathrm{O}$ values from Zone 3 differ by approximately $2 \%$ o between Trend I (-5.1\%o) and Trend II $(-3.1 \%$ o cements (Table 1$)$. Statistical tests were performed to determine whether the isotopic compositions of crystals in Trend I are indeed significantly different from that of crystals in Trend II. An analysis of variance (ANOVA; $a=0.05$ ) indicates that the isotopic compositions of crystals associated with Trend I are statistically different from those of crystals associated with Trend II $\left(F=24.7\right.$ and $F_{\text {critical }}=4.7$, where $F>F_{\text {critical }}$ indicates that data populations are significantly different).

Differences in the slopes of covariances in cement $\delta^{18} \mathrm{O}$ and $\delta^{13} \mathrm{C}$ values can be correlated with lumines- cence characteristics and regional stratigraphic distribution (Figure 3). Crystals with Trend II isotopic compositions contain Zones 1, 2, and 3, and are restricted to the northern part of the study area, immediately adjacent to the pre-Pennsylvanian exposure surface. In contrast, crystals with Trend I compositions occur throughout the rest of stratigraphic sequence, and thus make up the volumetric bulk of Mississippian cement. Most of these contain Zones 1 and 2 only, with the exception of a few from the northern part of the field area, at the uppermost stratigraphic levels where crystals with Trend I isotopic compositions occur.

In addition to cement data, $\delta^{18} \mathrm{O}$ and $\delta^{13} \mathrm{C}$ values from crinoid columnals, on which cement crystals nucleated, also lie along Trend I and Trend II (Figure 5B; Table 1). Moreover, $\delta^{18} \mathrm{O}$ and $\delta^{13} \mathrm{C}$ values from these components generally lie between the most positive and most negative values of the same covariant trend as their syntaxial cement overgrowths. Not surprisingly, this suggests that isotopic compositions of crinoid debris represent various mixtures of neomorphosed columnal carbonate and secondary calcite cement. Analysis of variance demonstrates that the compositions of crinoid grains are statistically identical to those of their cement overgrowths (Trend II: $F=1.4$ and $F_{\text {critical }}=5.1$; Trend I: $F=0.001$ and $F_{\text {critical }^{\prime}}=7.7$ ).

Although $\delta^{18} \mathrm{O}$ values from speleothems (Figure 5B) are similar to those from Zone 3 in Trend II cement $(-3.3 \pm 0.5 \%$ o $), \delta^{13} \mathrm{C}$ values $(-7.6 \pm 0.5 \%$ ) are significantly more negative than those from either cements or crinoid debris. In contrast to the marked heterogeneity observed in the compositions of cement and echinoderms, the oxygen isotope composition of speleothems is relatively uniform.

\subsection{Minor elements}

Although bulk Mg concentrations in syntaxial cement are generally similar, compositions of individual CL zones and intracrystalline trends from substrates to terminations differ between crystals in Trend I and Trend II. Trend I crystals show little spatial variation in $\mathrm{Mg}$ content $\left(0.46 \pm 0.04\right.$ mole $\left.\% \mathrm{MgCO}_{3}\right)$, and Zone 1 and Zone 2 differ in average $\mathrm{Mg}$ content by less than 0.05 mole\% (Figure 6). Trend II cements have $\mathrm{Mg}$ contents that vary by as much as $0.2 \mathrm{~mole} \%$ 


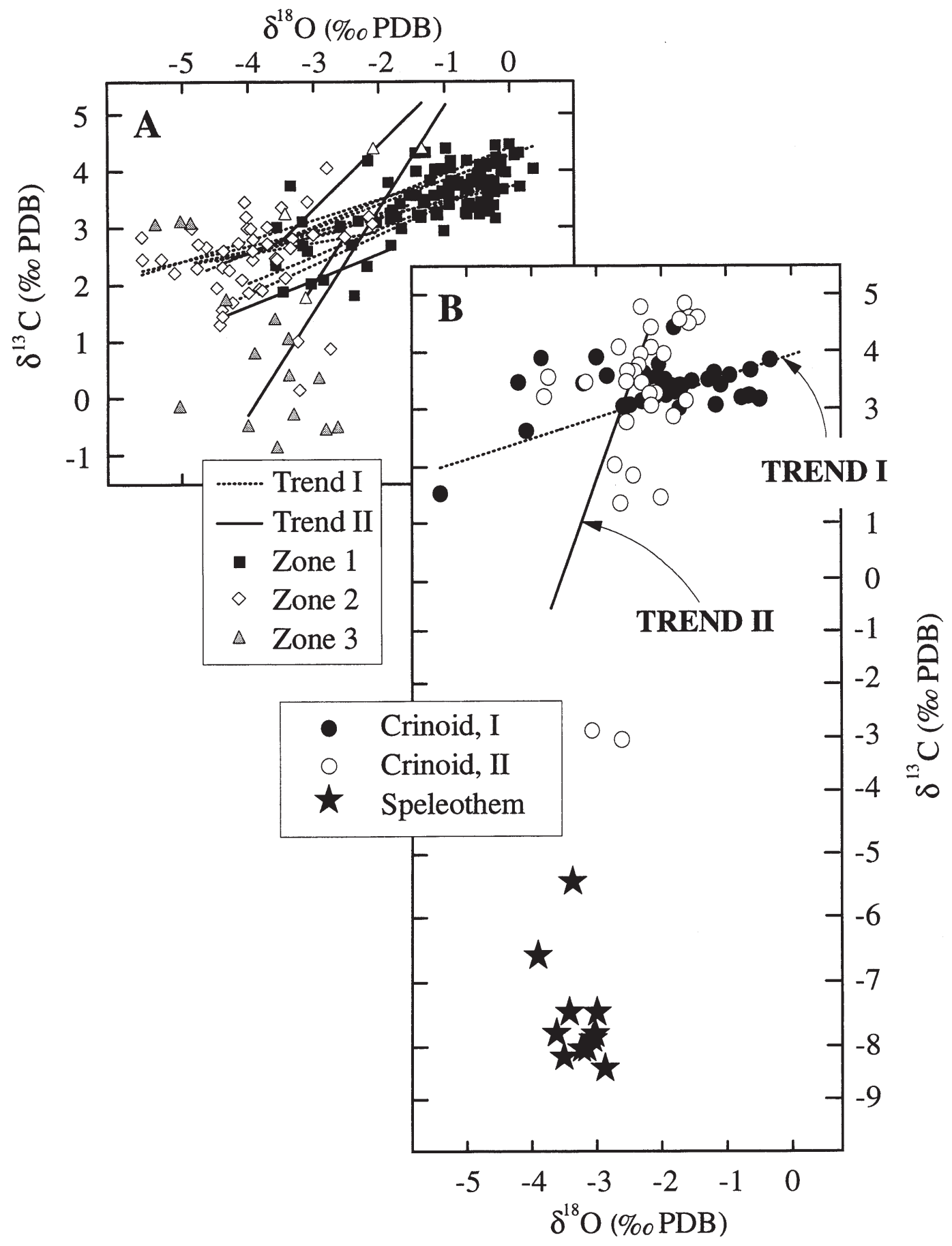

Figure 5. Carbon and oxygen isotope compositions of syntaxial cement, crinoid debris, and speleothems. (A) Covariance of $\delta^{13} \mathrm{C}$ and $\delta^{18} \mathrm{O}$ values from all analyzed cement crystals. Solid and dashed lines show principal axes of covariation for data from individual crystals $(n=15)$. Note that crystals in Trend I (dashed lines) show more variability in oxygen isotope composition but less variability in carbon isotope composition than do crystals in Trend II (solid lines). (B) $\delta^{13} \mathrm{C}$ and $\delta^{18} \mathrm{O}$ values from crinoid debris and speleothems and principal axes of covariation for Trend I (dashed) and Trend II (solid) cement data. Slopes and correlation coefficients for Trend I and Trend II cement data differ markedly (Trend II: $m=3.23 ; r^{2}=0.66$; Trend I: $m=0.36 ; r^{2}=0.89$ ). Also note that $\delta^{13} \mathrm{C}$ and $\delta^{18} \mathrm{O}$ values from crinoid debris lie between the most positive and most negative values from associated cement overgrowths. Speleothems have $\delta^{18} \mathrm{O}$ values similar to Zone 3 and associated crinoids in Trend II, while $\delta^{13} \mathrm{C}$ values are significantly more negative than values from either cements or crinoids. 
$\mathrm{MgCO}_{3}$ from near crystal substrates to terminations (Figure 6). Mg content is the highest in Zone 1 (0.3 \pm 0.04 mole $\% \mathrm{MgCO}_{3}$ ), and decreases through Zones 2 and 3 to $0.2 \pm 0.04$ and $0.09 \pm 0.04$ mole $\% \mathrm{MgCO}_{3}$, respectively. $\mathrm{Mg}$ content in speleothems is similar to Zone 3 in Trend II cement $\left(0.1 \pm 0.03\right.$ mole $\left.\% \mathrm{MgCO}_{3}\right)$.

In all cases, Mn content reflects the luminescence of cement zones and speleothems. Mn is generally below 400 ppm in Zones 1 and 3 of Trend I cement, and below EMPA detection limits in Zones 1 and 3 of Trend II cement. In speleothems, Mn content is extremely low (55 \pm 33 ppm). Mn content increases to over 1000 ppm in luminescent Zone 2 of Trend I cement and is $357 \pm 64$ ppm in Zone 2 of Trend II cement.

\section{Discussion}

The pattern in $\delta^{18} \mathrm{O}$ and $\delta^{13} \mathrm{C}$ values from Trend II cement is similar to that obtained by Meyers and

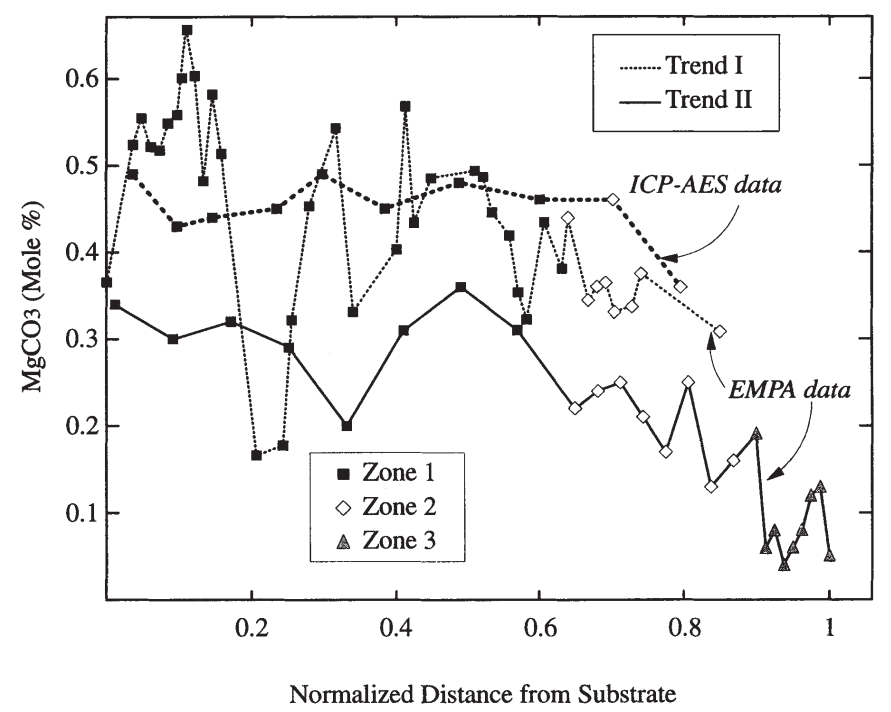

Figure 6. $\mathrm{Mg}$ concentration versus distance from substrate for Trend I and Trend II cement. Mg content is generally uniform across Zone 1 and Zone 2 in Trend I cement. Mg concentrations in Trend II cement are generally lower, and decrease across Zones 1, 2, and 3.

Table 1. Statistical summary of carbon and oxygen isotope data from individual cement crystals and echinoderm grains, tabulated according to Trend I and Trend II

\begin{tabular}{|c|c|c|c|c|c|c|c|}
\hline Section & Sample \# & Stratigraphic Unit & $n$ & Slope & Intercept & $r^{2}$ & $\begin{array}{c}\delta^{18} \mathrm{O} \\
\text { Zone } 3\end{array}$ \\
\hline & TREND I & & 131 & 0.36 & 3.96 & 0.89 & -5.1 \\
\hline 3 & 1 & Bioherm flank & 5 & 0.24 & 3.59 & 0.21 & -5.1 \\
\hline 3 & 2 & " & 5 & 0.19 & 3.33 & 0.45 & - \\
\hline 4 & 1 & $"$ & 13 & 0.46 & 4.43 & 0.81 & - \\
\hline 4 & 2 & " & 18 & 0.52 & 3.94 & 0.86 & - \\
\hline 4 & 3 & " & 18 & 0.43 & 4.30 & 0.74 & - \\
\hline 4 & 4 & $"$ & 27 & 0.26 & 3.74 & 0.86 & - \\
\hline 4 & $5 \mathrm{~A}$ & " & 10 & 0.47 & 3.94 & 0.90 & - \\
\hline 4 & $5 B$ & $"$ & 23 & 0.34 & 3.82 & 0.67 & - \\
\hline 6 & 1 & " & 6 & 0.36 & 4.24 & 0.27 & -5.1 \\
\hline \multirow[t]{3}{*}{7} & 3 & " & 6 & 0.33 & 3.93 & 0.86 & - \\
\hline & Crinoids & & 50 & 0.24 & 3.76 & 0.28 & - \\
\hline & TREND II & & 21 & 3.23 & 11.55 & 0.66 & -3.1 \\
\hline 1 & 2 & Tierra Blanca & 9 & 1.8 & 6.98 & 0.77 & -3.8 \\
\hline 2 & $1 \mathrm{~A}$ & " & 2 & 1.77 & 7.37 & - & -3.2 \\
\hline 2 & $1 \mathrm{~B}$ & “ & 7 & 1.13 & 6.76 & 0.56 & -3.1 \\
\hline \multirow[t]{2}{*}{5} & 1 & $"$ & 3 & 0.46 & 3.49 & 0.72 & -2.3 \\
\hline & Crinoids & & 32 & 7.89 & 21.57 & 0.13 & - \\
\hline
\end{tabular}

Sample numbers increase with distance from the top of measured sections. Trend I and Trend II statistics are based on cement data only. Slopes and intercepts of principal axes of covariation and correlation coefficients were calculated according to Sokal and Rohlf (1969). 
Lohmann (1985), who interpreted this to be the result of cement precipitation from meteoric water that was modified compositionally during dissolution of metastable marine carbonate host rock and precipitation of syntaxial cement. In comparison, the shallow linear covariance in Trend $\mathrm{I} \delta^{18} \mathrm{O}$ and $\delta^{13} \mathrm{C}$ values is incompatible with patterns predicted to result from such water-rock exchange reactions (Lohmann, 1988; Banner and Hanson, 1990), and therefore must reflect a different diagenetic process.

In addition to suggesting different mechanisms for cementation in the lower and upper Lake Valley Formation, the $2 \%$ difference in Zone $3 \delta^{18} \mathrm{O}$ values between Trend I and II cement suggests that Zone 3 in Trend I cement is not coeval with Zone 3 in Trend II cement. Cementation must therefore have occurred in the presence of two meteoric waters with different oxygen isotope compositions. This implies that Zone 3 cement in the lower and upper parts of the formation are not related to the same pre-Morrowan episode of exposure, but rather to two temporally separate events (two different meteoric fluids). Although this scenario might suggest that Trend II cement crystals should in some cases directly overlie Trend I crystals, this relationship has not been observed. This could perhaps be attributed to: (1) stabilization of metastable carbonate in the lower part of the stratigraphic section during Trend I time; or (2) restriction of the meteoric system associated with Trend II cement to upper stratigraphic levels.

\subsection{Trend I cement}

The robust covariance shown by isotope data from Trend I cement is incompatible with L-shaped patterns predicted to occur in cement precipitated from meteoric water modified compositionally during solubility-driven exchange with the host rock (Lohmann, 1988; Banner and Hanson, 1990), and must reflect either: (1) post-depositional alteration of an original cement phase by solid-state diffusion or heterogeneous replacement; or (2) modifications during cementation via kinetic- or temperature-induced change in fluidsolid fractionation or change in the composition of the ambient fluid during precipitation. On the basis of stratigraphic, petrographic, and geochemical considerations, Frank and Lohmann (1995) concluded that these linear covariances in cement chemistry resulted from precipitation during mixing between Mississippian marine and meteoric fluids.

\subsubsection{Marine end member}

Estimates of the isotopic compositions for Mississippian marine and meteoric water can be used to determine the relative contributions of these two fluids during cementation. The $\delta^{18} \mathrm{O}$ value of Mississippian marine calcite has been estimated from analyses of brachiopod valves (Popp et al., 1986; Veizer et al., 1986; Banner and Kaufman, 1994) and from former fibrous high-magnesium calcite marine cement (Meyers and Lohmann, 1985; Dunn, 1988; Douthit et al., 1993). In all six studies it was proposed that Lower Mississippian marine calcite has a $\delta^{13} \mathrm{C}$ value of about $+4.0 \%$ and a $\delta^{18} \mathrm{O}$ value of about $1.5 \%$ PDB. This estimate is similar to $\delta^{13} \mathrm{C}$ values, but significantly lower than the highest $\delta^{18} \mathrm{O}$ values observed in Zone 1 of Trend I cement. Patchy cathodoluminescence, however, demonstrates that both former magnesian calcite marine cement (Meyers and Lohmann, 1985; Dunn, 1988; Douthit et al., 1993) and brachiopod shell material (Popp et al., 1986; Veizer et al., 1986; Banner and Kaufman, 1994) have undergone at least partial diagenetic alteration since precipitation. In light of this, and because the preservation of luminescence banding in cement crystals indicates no alteration since precipitation (e.g., Pedone et al., 1994), the high $\delta^{18} \mathrm{O}$ and $\delta^{13} \mathrm{C}$ values observed in Zone 1 calcite $(-0.5 \%$ PDB and $+3.8 \%$ o PDB, respectively) are interpreted to accurately reflect the composition of the marine end member fluid (Frank and Lohmann, 1995). Considering stratigraphic and petrographic constraints, which suggest that precipitation of Trend I cement was related to sea level lowstands and/or subaerial exposure, precipitation from Mississippian seawater that was slightly modified by evaporation could account for the high $\delta^{18} \mathrm{O}$ values from Zone 1 cement relative to other estimates of the oxygen isotopic composition of Mississippian marine calcite (Frank and Lohmann, 1995).

\subsubsection{Meteoric end member}

In a context of cement precipitation from mixtures of marine and meteoric water, the most nega- 
tive Trend I cement $\delta^{18} \mathrm{O}$ value (-5.6\% $\%$ PD) could be considered the maximum possible $\delta^{18} \mathrm{O}$ value of calcite precipitated from the meteoric end member. Alternatively, because the isotopic composition of Zone 3 in Trend I cement (Figure 3) defines a pattern of variable $\delta^{13} \mathrm{C}(-0.9$ to $+3.1 \%$ o PDB $)$ and generally invariant $\delta^{18} \mathrm{O}$ values $(-5.1 \pm 0.2 \%$ o PDB $)$ that is typical for cement precipitated during meteoric alteration, the probable $\delta^{18} \mathrm{O}$ value for Mississippian meteoric calcite can be constrained to $-5.1 \%$ o $\pm 0.2 \%$ o PDB (Lohmann, 1988; Banner and Hanson, 1990). Although $\delta^{18} \mathrm{O}$ values of several microsamples are more negative than this estimate, a range of only $\pm 0.5 \%$ in the $\delta^{18} \mathrm{O}$ value of meteoric water could account for all variation in Trend I cement. Such variation is not unusual for meteoric groundwater in modern carbonate terranes (e.g., Budd, 1984).

\subsubsection{Marine-meteoric mixing model}

Because the substantial variation shown by most natural waters makes it difficult to predict the saturation state for any given fluid mixture (Runnels, 1969), the marine-meteoric mixing zone is perhaps the most poorly understood and least documented of near-surface diagenetic settings. For instance, numerical simulations (e.g.. Runnels, 1969; Plummer, 1975; Wigley and Plummer, 1976) predict: (1) oversaturation with respect to calcite in mixtures containing anywhere from $>20$ to $>70 \%$ marine water, which generally corresponds to the lower parts of the mixing zone; (2) undersaturation with respect to calcite in mixtures containing 5 to $70 \%$ marine water, consistent with mixtures found in the middle and upper parts of the mixing zone; and (3) saturation with respect to calcite in mixtures containing < 5 to $15 \%$ marine water, such as those found in the dilute upper part of the mixing zone. The large and overlapping ranges of mixtures and their predicted saturation states attest to the potential not only for dissolution in the mixing zone, but also for calcite precipitation from a substantial range of marinemeteoric mixtures. Importantly, in mixing simulations where the temperature, $\left[\mathrm{HCO}_{3}{ }^{-}\right]$, and $P_{\mathrm{CO}_{2}}$ of fluid end members are similar, the range of mixtures oversaturated with respect to calcite can expand to encompass the full extent of mixing (e.g., Plummer, 1975, Figure 8). A modern example of mixing zone cementation under such conditions was recently documented in a geochemical study of Late Pleistocene aragonite cement from the Barbados by Kimbell and Humphrey (1994). $\delta^{18} \mathrm{O}$ and $\delta^{13} \mathrm{C}$ values from this cement show a linear covariance, and are consistent with precipitation from mixtures ranging from $25 \%$ to $50 \%$ modern meteoric with modern marine water from the same locality.

Using the estimated $\delta^{18} \mathrm{O}$ values for marine and meteoric calcite, it is apparent that both marine and meteoric waters were significant contributors during the precipitation of Trend I cement (Figure 7). These calculations suggest: (1) that most Zone 1 cement formed from mixtures containing more than $85 \%$ marine water, the remainder from mixtures containing as little as $60 \%$, and therefore likely precipitated in the marine phreatic zone and the lowermost marine-meteoric mixing zone; (2) that Zone 2 formed primarily from mixtures with 15 to $35 \%$ marine water in the middle to upper parts of the mixing zone; and (3) that Zone 3 precipitated in the meteoric phreatic zone from the meteoric end member whose carbon isotope composition and minor element content was likely modified by water-rock exchange.

The trend from more positive (marine) to more negative (meteoric) cement $\delta^{18} \mathrm{O}$ values with increasing distance from substrates suggests that cementation occurred during the progressive addition of meteoric water, probably during the gradual expansion of a freshwater lens. Volumetrically, up to $60 \%$ of Trend I cement (estimated from CL photomicrographs) formed from mixtures containing more than $85 \%$ marine water, while progressively smaller volumes precipitated from increasingly dilute solutions. In this context, the volume of calcite precipitated from various fluid mixtures could reflect change in the calcite saturation state during mixing (Figure 8). Only minor amounts of calcite formed from mixtures containing 40 to $70 \%$ marine water (Figs. 7,8 ), which is within the range commonly predicted to be undersaturated with respect to calcite (Plummer, 1975; Wigley and Plummer, 1976). This range of mixtures corresponds to the boundary between Zone 1 and Zone 2, at which Meyers (1978) reported rare petrographic evidence, not observed in samples used in this study, for localized hiatuses during precipitation. Alternatively, crystal thickness could reflect the length of 


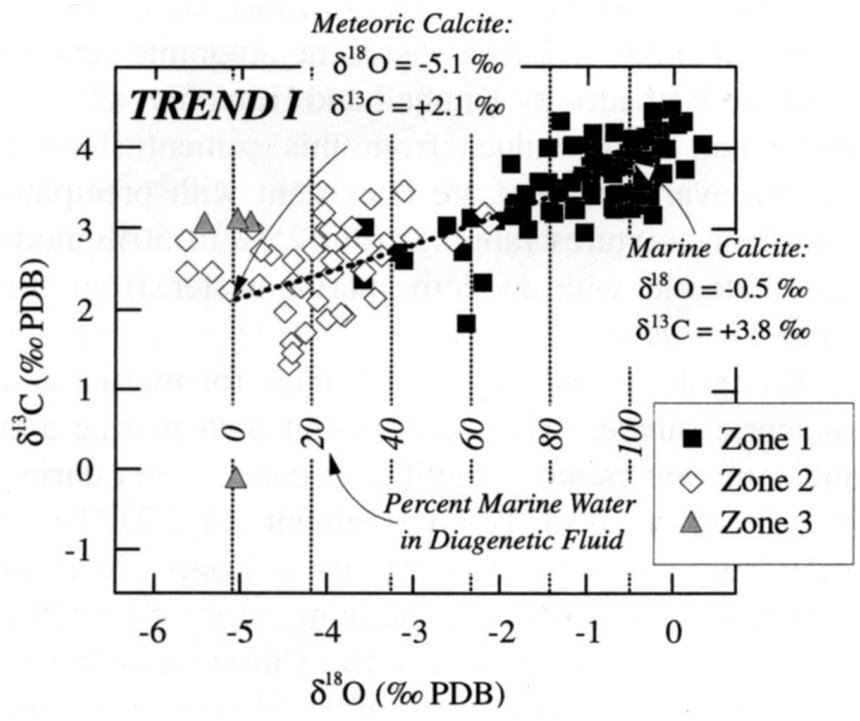

Figure 7. Marine-meteoric mixing model for Trend I cement. Estimated isotopic composition of marine calcite is based on composition of Zone $1\left(\delta^{18} \mathrm{O}=-0.5 \%\right.$; $\delta^{13} \mathrm{C}=+3.8 \%$; ; estimated oxygen isotope composition of meteoric calcite is based on composition of Zone $3\left(\delta^{18} \mathrm{O}=-5.1 \%\right.$ ). Straight mixing line (dashed) requires that end member fluids have equal concentrations of dissolved carbon $\left(\mathrm{C}_{\mathrm{T}}=2.5 \mathrm{mmol} / \mathrm{kg} \mathrm{H} \mathrm{H}_{2} \mathrm{O}\right.$ for marine and meteoric end members; Lohmann, 1988).

time an area was exposed to a given fluid mixture, which would suggest that the rate of expansion of the freshwater lens increased with time.

\subsubsection{Minor element considerations}

In the context of the generally accepted genetic relationship between cement morphology and mineralogy, which suggests that equant low-Mg calcite crystals form from meteoric or dilute fluids with low $\mathrm{Mg} / \mathrm{Ca}$ ratios (e.g., Folk, 1974), the low Mg concentrations in Trend I cement are somewhat problematic. Indeed, on the basis of the equant morphology and consistently low Mg concentrations of Lake Valley Formation cements, previous workers have suggested that marine water had no significant role in their formation (Meyers and Lohmann, 1985; Meyers, 1989). However, there is growing evidence that many minor element distributions in natural carbonates may not reflect equilibrium (Reeder and Grams, 1987; Paquette and Reeder, 1995), and recent investigations of the $\mathrm{Mg}$ content of naturally occurring calcites and the fluids from which they formed have led several workers to conclude that genetic interpretations of carbonate cements based solely on their mor-

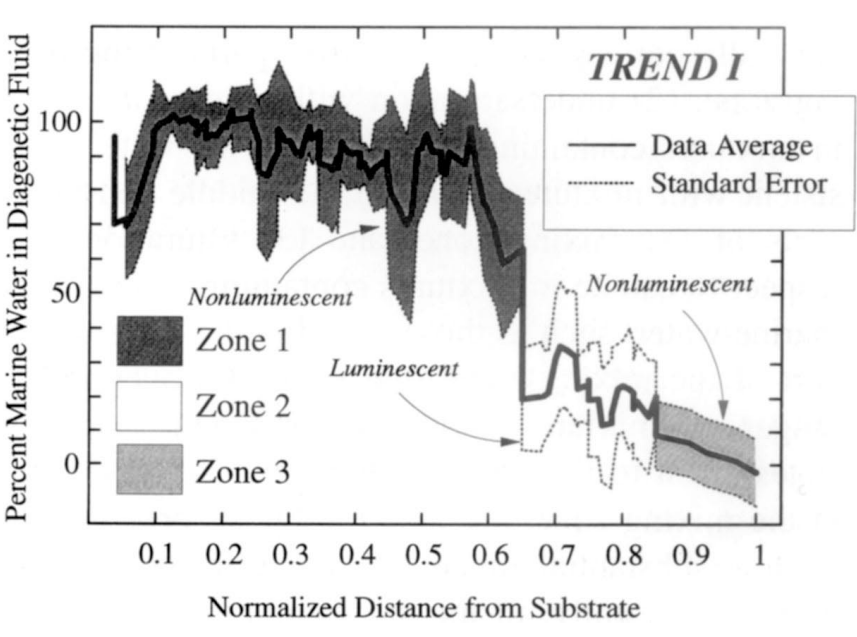

Figure 8. Percent marine water in the diagenetic fluid versus normalized distance from the substrate calculated as a running average over 5 microsamples for all Trend I cement. Oxygen isotope compositions of marine and meteoric end members estimated as in Figure 7. Boundaries of Zones 1, 2, and 3 were used to normalize positions of microsamples relative to crystal substrates as in Figure 4.

phology and/or Mg content should be treated with caution (Chafetz et al., 1985; Given and Wilkinson, 1985; Morse and Bender, 1990). Moreover, a number of investigators have combined petrographic evidence with isotope, minor-element, and fluid-inclusion data to suggest that equant, low-Mg calcite cements formed as primary marine precipitates in a number of Paleozoic sequences (e.g., Wilkinson et al., 1982; Miller, 1986; Carpenter et al., 1991; Johnson and Goldstein, 1993). Given this, it is not unreasonable to attribute the low $\mathrm{Mg}$ content in Trend I cement to precipitation of low-Mg calcite under conditions of slow growth within the marine phreatic and marine-meteoric mixing zones.

\subsubsection{Trend I cementation and chronostratigraphic signif- icance of CL zones}

An important difference between the mechanism for cementation proposed in this study for Trend I cement and the water-rock interaction scenario suggested previously lies in the inferred source for cement $\mathrm{CaCO}_{3}$. A water-rock interaction model assumes that $\mathrm{CaCO}_{3}$ is intrinsically sourced from dissolving metastable marine phases. Assuming that 
the original marine sediment had an initial porosity of 50\%, Meyers (1973, p. 198) indicated that approximately $137 \mathrm{~m}$ of overlying sediment must have been removed by dissolution to account for the volume of Mississippian cement that occurs in the Lake Valley Formation. This suggests that less than half of the original sediment pile is preserved. In contrast, the marine-mixing zone model proposed here suggests that $\mathrm{CaCO}_{3}$ is extrinsically sourced from supersaturated diagenetic fluids, and that the amount of material derived from dissolving metastable phases is not significant. Derivation of cement $\mathrm{CaCO}_{3}$ from the diagenetic fluid requires the movement of a substantial volume of water through available porosity. Although the number of pore volumes of fluid required to account for the volume of Mississippian cement in the Lake Valley Formation would vary depending on the saturation state of marine-meteoric mixtures, a reasonable estimate of approximately 50,000 pore volumes can be made assuming: (1) precipitation from a fluid with a calcite saturation state similar to that of modern seawater; and (2) that Mississippian cement occupies $74 \%$ of primary porespace in the Lake Valley Formation (Meyers, 1973). While it is difficult to constrain the mechanism for fluid pumping, recognizing that such flow in comparable modern settings occurs in response to tidal and wind-wave currents and mixing zone convection (Bathurst, 1975; Land, 1975; Land et al., 1989; Morse and Mackenzie, 1990) suggests that the extrinsic source of $\mathrm{CaCO}_{3}$ proposed here for Trend I cement is not unreasonable.

Petrographic and isotopic evidence support an external source for Trend I cement $\mathrm{CaCO}_{3}$. The correspondence between the isotopic compositions of crinoids and their Trend I or Trend II cement overgrowths suggests that cementation of crinoid columnals occurred coevally with the precipitation of associated syntaxial cement. Thus, it appears that crinoids in the upper part of the Lake Valley Formation remained unaltered during Trend I cementation. Moreover, the regional isotopic uniformity among Trend I crystals suggests that water-rock interaction was not modifying the composition of the diagenetic fluid during the emplacement of Trend I cement. Significant inputs of dissolving metastable marine calcite would have likely resulted in a regional and stratigraphic dependence on the isoto- pic pattern observed in Trend I cement crystals as a function of their proximity to the source of dissolving phases, and/or differences in the number of water-rock exchange reactions encountered by the diagenetic fluid. With this in mind, the nature of the pattern in isotopic composition observed in all Trend I cement, wherein $\delta^{18} \mathrm{O}$ and $\delta^{13} \mathrm{C}$ values are more positive (marine) near substrates and become more negative (meteoric) towards crystal terminations, suggests that cementation occurred during the progressive addition of meteoric water.

The association between $\delta^{18} \mathrm{O}$ and $\delta^{13} \mathrm{C}$ values and luminescence observed in all Trend I cement crystals (Figures 5, 7, \& 8) implies a concurrent relationship between redox conditions and the isotopic composition of the diagenetic fluid. This, in turn, suggests that CL zoning may have stratigraphic significance in the lower part of the stratigraphic section. Studies of groundwater chemistry show that there is often stratification in marine-meteoric mixing zones with regard to fluid isotopic compositions (Back and Hanshaw, 1970; Budd and Land, 1985), and also demonstrate that reducing conditions often prevail in the distal portions of meteoric systems (Champ et al., 1979). Such stratification would allow for the precipitation of nonluminescent marine calcite in the marine phreatic and lowermost mixing zone, precipitation of luminescent calcite in the middle to upper mixing zone, and nonluminescent calcite in the meteoric phreatic zone, as predicted by numerical modeling (Figs. 7, 8). In this context, the regional stratigraphic distribution of Trend I cement suggests that the marine-meteoric mixing zone must have passed gradually through the various stratigraphic levels where Trend I cement is found to allow the same set of isotopic compositions and redox conditions to occur at all stratigraphic levels (Figure 9). This suggests that Trend I cement precipitated at different times at different stratigraphic levels, and implies that the boundaries of CL zones in Trend I cement are diachronous in this dynamic diagenetic setting. Considered in a stratigraphic context, the occurrence of Trend I cement in both shallow subtidal grainstones (Tierra Blanca Member) and overlying deeper-water mudstones and packstones (Arcente and Dona Ana Members) indicates that basinward migration of the freshwater lens was not related to basinward progradation during deposition, but 
rather was post-depositional and more likely related to pre-Pennsylvanian lowering of sea level postulated by Vail and Mitchum (1975) and manifest in the Sacramento Mountains as a regional unconformity.

\subsection{Trend II cement}

Stable isotope and minor element data from crystals in Trend II are consistent with the previous study by Meyers and Lohmann (1985). Although it is difficult to distinguish between Zone 1 of Trend II and Trend I cements isotopically, several observations suggest that they are distinct populations. These include: (1) $\mathrm{Mg}$ contents that are higher in Zone 1 of Trend I cement than in Trend II; (2) $\delta^{18} \mathrm{O}$ values from near the substrate in Zone 1 of Trend I cement that are more positive than those from near the substrate in Zone 1 of Trend II cement; and (3) $\delta^{18} \mathrm{O}$ and $\delta^{13} \mathrm{C}$ values from Zone 1 in Trend II cement that are not strongly colinear in comparison to Zone I values from Trend I cement. In addition, the overall trend defined by data from Trend I and Trend II cements must be considered. $\delta^{18} \mathrm{O}$ and $\delta^{13} \mathrm{C}$ values from Trend I cement form a linear mixing trend, while values from Trend II cement form a nonlinear pattern that is compatible with predictions for cement precipitated from fluid modified compositionally during progressive dissolution of metastable marine carbonate and precipitation of low-Mg calcite (Figure 10; Lohmann, 1988).

\subsubsection{Meteoric fluid end member}

When the mass balance of water-rock exchange reactions is considered, the relative water-rock ratios at which the carbon and oxygen isotope compositions of the meteoric fluid equilibrate with those of the host rock can be determined. Because mole fractions of carbon differ significantly in water and rock reservoirs (oxygen concentrations, in contrast, are roughly equal), the isotopic composition of meteoric water (and cement) should evolve such that fluid carbon isotope compositions equilibrate more rapidly with marine carbonate than do fluid oxygen isotope compositions (Lohmann, 1988; Banner and Hanson, 1990). As a result, the $\delta^{18} \mathrm{O}$ and $\delta^{13} \mathrm{C}$ values of the fluid (and cement) in meteoric diagenetic systems typically define L-shaped patterns of constant $\delta^{18} \mathrm{O}$ and variable $\delta^{13} \mathrm{C}$

\section{Trend I Cementation} (pre-Rancheria)

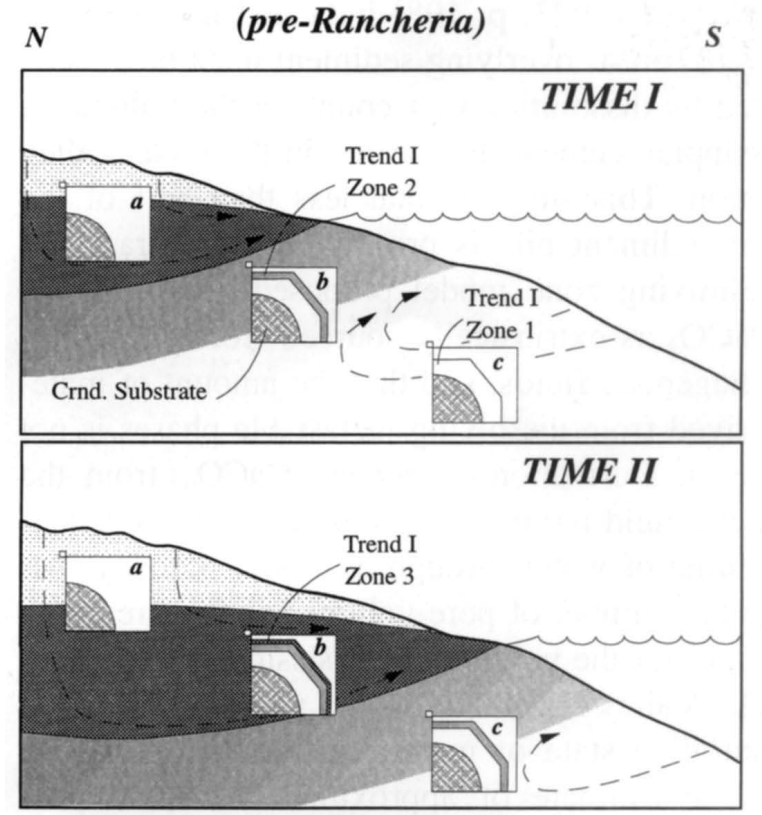

Trend II Cementation (post-Rancheria)

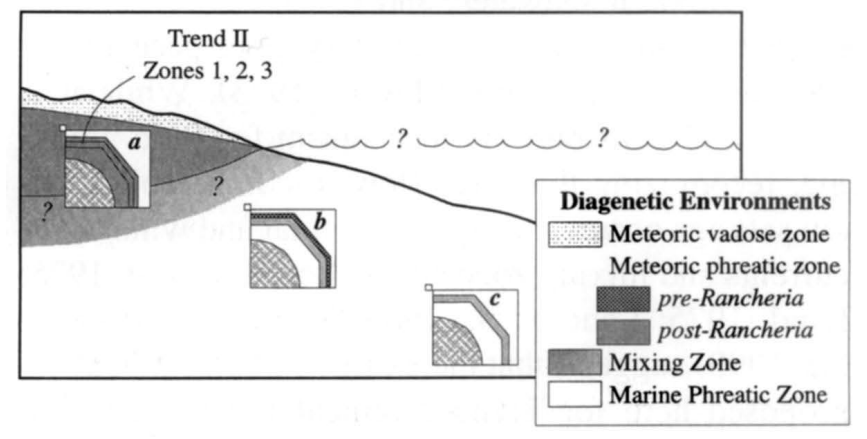

Figure 9. Schematic model for emplacement of Trend I and Trend II cements. Inset figures $a, b$, and $c$ show the relative timing for precipitation of Zone 1, Zone 2, and Zone 3 in Trend I and Trend II cement and the diagenetic environments in which they formed. Trend I Cementation: a drop in sea level prior to deposition of the Rancheria Fm. moved the marinemeteoric mixing zone through the stratigraphic sequence. Arrows denote fluid flow. Trend I cement (and cement CL Zones 1,2 , and 3) at stratigraphic levels b and c formed at different times; boundaries of CL zones are diachronous. Trend II Cementation: Trend II cement formed entirely within a meteoric phreatic zone that was established after deposition of the Rancheria Fm. and prior to deposition of overlying Pennsylvanian units. The chronostratigraphic significance of CL zones in Trend II cement is ambiguous.

and/or variable $\delta^{18} \mathrm{O}$ and constant $\delta^{13} \mathrm{C}$ values, depending on the water-rock ratio attained in that part of the meteoric system (Lohmann, 1988). The pattern 
of invariant $\delta^{18} \mathrm{O}$ values coupled with highly variable $\delta^{13} \mathrm{C}$ values is termed the meteoric calcite line, and delineates the $\delta^{18} \mathrm{O}$ value of calcite typical for the oxygen isotope composition of the meteoric water from which diagenetic products formed (Allan and Matthews, 1982; Lohmann, 1988).

Trend II cement data define a meteoric calcite line with an average $\delta^{18} \mathrm{O}$ value of $-3.1 \pm 0.7 \%$ o PDB (Figure 10). Significantly, this is nearly identical to the mean $\delta^{18} \mathrm{O}$ value of co-occurring speleothems (-3.3 $\pm 0.5 \%$ PDB). Moreover, because the oxygen isotope composition of speleothems more closely matches that of Trend II cement than either modern flowstone in the Sacramento Mountains $\left(\delta^{18} \mathrm{O}=-9.0 \%\right.$ o $\mathrm{PDB})$, meteoric calcite in overlying Virgilian units $\left(\delta^{18} \mathrm{O}=-5.5 \%\right.$ o PDB; Goldstein, 1991), or Trend I meteoric calcite, it is likely that speleothems are indeed pre-Morrowan as suggested by Goldstein (1990), and related to the same meteoric system as Trend II cement. Although field relations demonstrate that speleothems post-date Trend II cement (Goldstein, 1990), they provide additional constraints for the oxygen and carbon isotope composition of the meteoric fluid from which these components precipitated. Cement isotopic compositions reflect more extensive water-rock exchange in a terrane still made up largely of metastable carbonate phases. On the other hand, speleothem compositions reflect the diminishing availability of such phases with time as the rock system matured, and thus more closely resemble the composition of the unreacted meteoric fluid end member. This allows the $\delta^{18} \mathrm{O}$ value for meteoric water to be constrained to $-1.3 \pm 0.5 \%$ o SMOW, assuming precipitation at $25^{\circ} \mathrm{C}$ (Friedman and $\left.\mathrm{O}^{\prime} \mathrm{Neil}, 1977\right)$. In addition, the most negative speleothem $\delta^{13} \mathrm{C}$ value can be considered the best estimate for the value of pure meteoric calcite $\left(\delta^{13} \mathrm{C}=\right.$ $-9.1 \%$ PDB), which suggests rather typical $\delta^{13} \mathrm{C}$ values for ambient (soil) $\mathrm{CO}_{2}$ (g) (-18.0 to $-20.0 \%$ PDB; Romanek et al., 1992).

\subsubsection{Water-rock exchange model}

Low calculated water-rock ratios and the nearmarine isotopic composition of Zone 1 calcite indicate that a high degree of water-rock exchange was attained in that part of the meteoric system where Trend II cement occurs (Figure 10). In addition, the

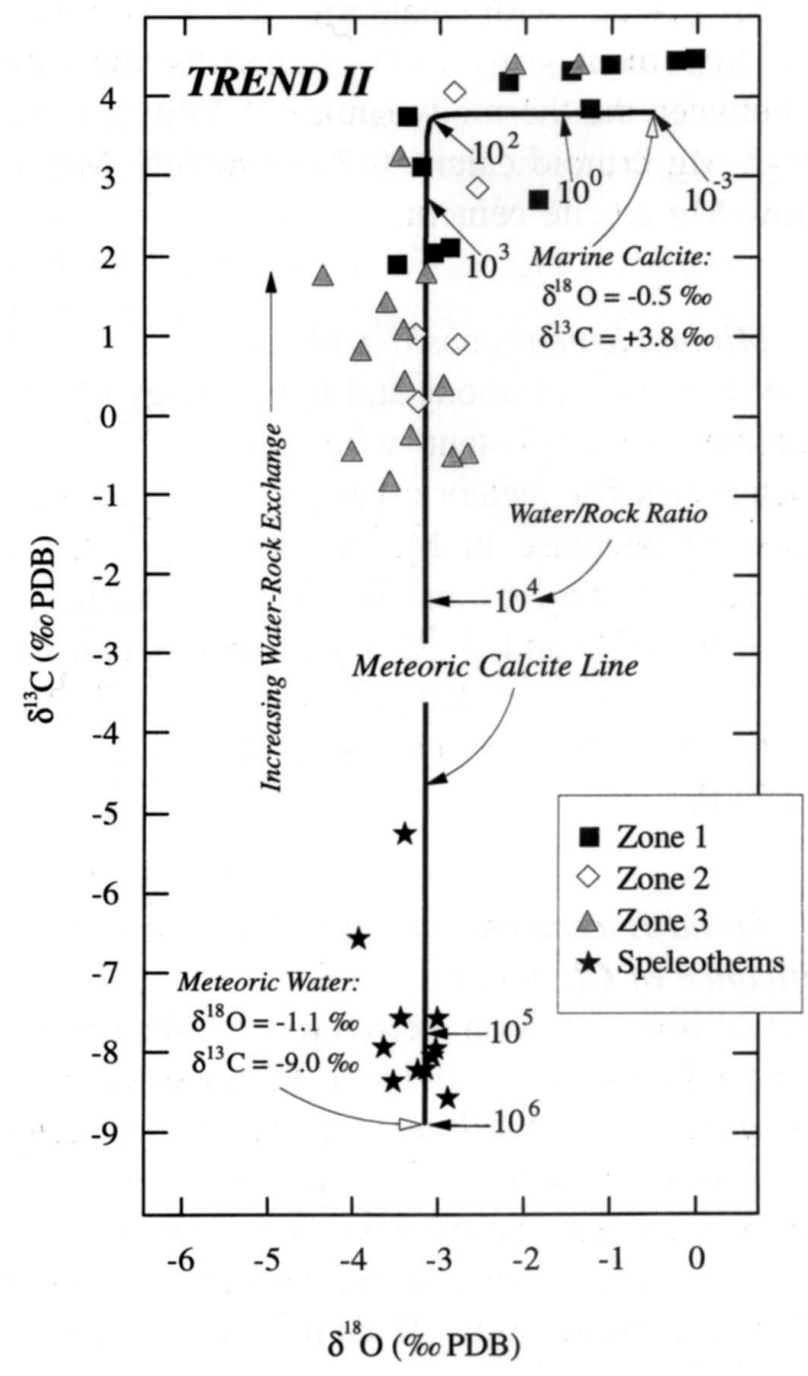

Figure 10. Water-rock interaction model for Trend II cement. Numerical modeling tracked the evolution of the isotopic composition of meteoric water in response to the incremental addition of carbonate during progressive water-rock exchange. Increment size was constrained by the difference between the thermodynamic solubility constants for high-Mg (echinoderm) calcite and low-Mg calcite cement. Estimated oxygen isotope composition of meteoric water is based on meteoric calcite line defined by Trend II cement and speleothem data $\left(\delta^{18} \mathrm{O}=\right.$ $1.3 \%$ o SMOW at $25^{\circ} \mathrm{C}$ ); carbon isotope composition is based on composition of speleothems $\left(\delta^{13} \mathrm{C}=-9.1 \%\right.$ PDB $)$.

progressive increase in calculated water-rock ratios for Zone 1, Zone 2, Zone 3, and speleothems, respectively, reflect decreasing water-rock exchange as primary marine metastable carbonate phases were diagenetically stabilized. The numerical simulation of water-rock exchange used in this study is solubilitydriven and based on the incremental reaction of high- 
Mg calcite with meteoric water (Lohmann, 1988). Increment size is constrained by the difference between the thermodynamic solubility constants for high-Mg crinoid calcite (12-18 mole $\% \mathrm{MgCO}_{3}$ ) and low-Mg calcite cement.

\subsubsection{Minor element considerations}

Low Mg concentrations and morphology of Trend II cement are consistent with generally accepted characteristics for meteoric cement. In addition, the progressive decrease in $\mathrm{Mg}$ concentrations through Zones 1, 2, 3 (Figure 6) and speleothems mirrors the decrease in $\delta^{18} \mathrm{O}$ and $\delta^{13} \mathrm{C}$ values, and is consistent with a water-rock exchange scenario for Trend II cement (Brand and Veizer, 1980; Banner and Hanson, 1990).

\subsubsection{Trend II cementation and chronostratigraphic sig- nificance of $C L$ zones}

The striking relation between isotopic composition and CL zoning in all Trend I cement crystals is not observed in Trend II cement. Although a general decrease in $\delta^{18} \mathrm{O}$ and $\delta^{13} \mathrm{C}$ values of Zones 1 to 3 is probably related to progressive stabilization of host carbonate during cementation, absolute $\delta^{18} \mathrm{O}$ and $\delta^{13} \mathrm{C}$ values from Trend II cement CL zones vary among different crystals. Similarly, values from individual crystals typically cover only a part of the inferred water-rock interaction trend. A pattern emerges only when data from all crystals are examined concurrently (Figure 10). This intercrystalline variability in isotopic composition probably reflects irregularly distributed, local differences in the carbon and oxygen isotope composition of meteoric pore water. Such heterogeneity is a common feature of the upper parts of modern freshwater lenses, and can result from local differences in porosity, degree of stabilization of the host rock (mineralogy), or fluctuations in the thickness of the freshwater lens (e.g., Budd and Land, 1990). Importantly, these processes serve to differentially modify meteoric pore fluid compositions such that they collectively verify predictions based on water-rock exchange modeling. Thus, despite geochemical differences among crystals, the overall pattern that emerges from Trend II cement data defines a unique $\delta^{18} \mathrm{O}$ value for meteoric calcite, which is distinct from that for Trend I cement. The lack of correlation between CL zones and isotopic composition in Trend II cement, however, renders the chronostratigraphic significance of CL zoning somewhat ambiguous. Boundaries of CL zones either have no stratigraphic significance and are related to stochastic changes in local redox conditions, or they are synchronous and record pervasive change in the redox state of the fluid that is independent of isotopic composition (Figure 9).

\subsection{Constraints on the relative timing of Trend I and Trend II cementation}

Regional and stratigraphic relations between CL zoning and intracrystalline isotopic composition demonstrate that diverse and temporally distinct diagenetic settings can produce identical CL characteristics. These relations further demonstrate that the cement CL stratigraphy previously applied to this sequence cannot be of chronostratigraphic significance over the full regional extent of the Lake Valley Formation, and calls for caution when using cement CL stratigraphy alone to extend diagenetic interpretations over large geographic regions or through substantial stratigraphic sequences. However, distribution of cement CL zones adjacent to exposure surfaces can be used in conjunction with cement chemistry to aid in constraining the relative timing of Trend I and Trend II cement precipitation. With the exception of stratigraphic levels immediately adjacent to the prePennsylvanian unconformity in the northern part of the study area. Trend I cement is present throughout the Lake Valley Formation at all stratigraphic levels. Reworked grainstone clasts in the basal part of the Rancheria Formation (Section 7, Figure 3) contain remnants of CL Zones 1 and 2 (Meyers, 1974). Zone 3 is absent from this material, suggesting that this detrital material may contain Trend I cement. Although irregularity of these cement rims precluded microsampling and isotopic analysis, these petrographic relations imply that Trend I cement is pre-Meramecian and was emplaced prior to deposition of the Rancheria Formation. Examination of cement zone chemistry and distribution at the pre-Morrowan exposure surface in the northern part of the study area (Sections 1-3, Figure 3) clearly indicates that Trend II cement is pre-Morrowan (Meyers, 1974, 1978). Although the 
absence of Rancheria strata in this area makes it difficult to evaluate the timing of Trend II cementation relative to pre-Meramecian exposure, restriction of Trend II cement to areas cratonward (north) of Rancheria deposition, and the absence of Zone 3 cement on reworked grains in basal Rancheria rocks (Meyers, 1974), implies that Trend II cement is post-Meramecian and younger than the Rancheria Formation.

These observations suggest that the meteoric system associated with Trend I cement is older and formed in response to pre-Meramecian exposure, while the (different) meteoric system from which Trend II cement precipitated is younger and formed during exposure following deposition of the Meramecian Rancheria Formation (Figure 9). Regardless of the exact timing of cementation in the upper part of the Lake Valley Formation relative to the lower part, the implication that Trend I and Trend II cements and associated meteoric systems are temporally separated allows sufficient time for change that could have affected the oxygen isotope composition of local meteoric water, such as change in the location of the recharge zone or regional climate, and could thus account for a $2 \%$ shift in the $\delta^{18} \mathrm{O}$ value of meteoric calcite between the emplacement of Trend I and Trend II cements.

\section{Conclusions}

At present, the Lake Valley Formation serves as a principal reference section for cement CL stratigraphy, and for the interpretation of meteoric cementation through isotopic and elemental techniques. While the fundamentals of previous studies remain valid, data presented here suggest that the specifics of the diagenetic evolution and the dominant settings in which cementation of this sequence occurred are more complicated than suggested by cement CL stratigraphy alone. Rather than a single event of subaerial exposure and meteoric diagenesis, stable isotope data suggest that at least two distinct meteoric systems altered this sequence. This indicates that CL cement stratigraphy is not necessarily of chronostratigraphic significance when examined in a stratigraphic or regional context. In addition, the fundamental cementation model commonly called upon to interpret the early cementation of carbonate sediments, the solubility-driven redistribution of internally sourced carbonate within the meteoric phreatic zone, appears to be useful for only a minor and likely separate phase of the early diagenetic history of this sequence. Data from this study indicate that the marine phreatic and marine-meteoric mixing zones are the principal diagenetic environments in which massive cementation of the Lake Valley Formation occurred.

\section{Acknowledgments}

The submitted version of this paper benefited greatly from extensive discussions and critical reviews of early drafts by B. Wilkinson and W. Patterson. J. Banner, P. Choquette, N. James, and B. Sellwood provided constructive reviews that led to significant improvements in the final version of this paper. Field assistance was provided by A. DolanLaughlin and S. Dunn. To these individuals, our sincere thanks. This paper represents a part of the Ph.D. dissertation of T. Frank. Funds for field and analytical work were provided by the Scott Turner Fund (University of Michigan) and by NSF grant EAR-9105903.

\section{References}

Allan, J. R. and Matthews, R. K., 1982. Isotope signatures associated with early meteoric diagenesis. Sedimentology, 29: 797-817.

Back, W. and Hanshaw, B. B., 1970. Comparison of chemical hydrogeology of the carbonate peninsulas of Florida and Yucatan. J. Hydrol., 10: 330-368.

Banner, J. L. and Hanson, G. N., 1990. Calculation of simultaneous isotopic and trace element variations during water-rock interaction with application to carbonate diagenesis. Geochim. Cosmochim. Acta, 54: 3123-2137.

Banner, J. L. and Kaufman, J., 1994. The isotopic record of ocean chemistry and diagenesis preserved in nonluminescent brachiopods from Mississippian carbonate rocks, Illinois and Missouri. Geol. Soc. Am. Bull., 106: 1074-1082.

Bathurst, R. G. C., 1975. Carbonate Sediments and their Diagenesis. Elsevier, Amsterdam, 658 pp. 
Brand, U. and Veizer, J., 1980. Chemical diagenesis of a multicomponent carbonate system, 1 . Trace elements. J. Sediment. Petrol., 50: 1219-1236.

Budd, D. A., 1984. Freshwater Diagenesis of Holocene Ooid Sands, Schooner Cays, Bahamas. Ph.D. Diss., University of Texas, Austin, Tex., 491 pp.

Budd, D. A., 1988. Petrographic products of freshwater diagenesis in Holocene ooid sands. Schooner Cays, Bahamas. Carbonates Evaporites, 3: 143-163.

Budd, D. A. and Land, L. S., 1990. Geochemical imprint of meteoric diagenesis in Holocene ooid sands. Schooner Cays, Bahamas; correlation of calcite cement geochemistry with extant groundwaters. J. Sediment. Petrol., 60: 361-378.

Budd, D. A., Hammes, U., and Vacher, H. L., 1993. Calcite cementation in the upper Floridan aquifer; A modern example for confined-aquifer cementation models? Geology, 21: 33-36.

Carpenter, S. J., Lohmann, K. C, Holden, P., Walter, L. M., Huston, T. J., and Halliday, A. M., 1991. $\delta^{18} \mathrm{O}$ values, ${ }^{87} \mathrm{Sr} /{ }^{86} \mathrm{Sr}$ and $\mathrm{Sr} / \mathrm{Mg}$ ratios of Late Devonian abiotic marine calcite. Implications for the composition of ancient seawater. Geochim. Cosmochim. Acta, 55: 1991-2010.

Chafetz, H. S., Wilkinson, B. H., and Love, K. M., 1985. Morphology and composition of non-marine carbonate cements in near-surface settings. In: N. Schneidermann and P. M. Harris (Editors), Carbonate Cements. Soc. Econ. Paleontol. Mineral. Spec. Publ., 36: 337-347.

Champ, D. R., Gulens, J., and Jackson, R. E., 1979. Oxidation-reduction sequences in ground water flow systems. Can. J. Earth Sci., 16: 12-23.

DeKeyser, T. L., 1978. The Early Mississippian of the Sacramento Mountains, New Mexico-An Ecofacies Model for Carbonate Shelf Margin Deposition. Ph.D. Dissertation, Oregon State University, 304 pp.

Dorobek, S. L., 1987. Petrology, geochemistry and origin of burial diagenetic facies, Siluro-Devonian Helderberg Group (carbonate rocks), central Appalachians. Am. Assoc. Pet. Geol. Bull., 71: 492-514.

Douthit, T. L., Meyers, W. J. and Hanson, G. N., 1993. Nonmonotonic variation of seawater ${ }^{87} \mathrm{Sr} /{ }^{86} \mathrm{Sr}$ across the Ivorian/ Chadian boundary (Mississippian, Osagean): evidence from marine cements within the Irish Waulsortian limestone. J. Sediment. Petrol., 63: 539-549.

Dunn, P. A., 1988. Dynamics of $\delta^{13} \mathrm{C}$ and $\delta^{18} \mathrm{O}$ Variation in the Devono-Carboniferous Succession of Belgium and Ireland. M.S. Thesis, University of Michigan, Ann Arbor, Mich., 55 pp.

Folk, R. L., 1974. The natural history of crystalline calcium carbonate: Effect of magnesium content and salinity. J. Sediment. Petrol., 44: 40-53.

Frank, T. D. and Lohmann, K. C, 1995. Early cementation during marine-meteoric fluid mixing: Mississippian Lake Valley Formation, New Mexico. J. Sediment. Res., A65: 263-273.

Friedman, G. M., 1964. Early diagenesis and lithification in carbonate sediments. J. Sediment. Petrol., 34: 777-813.

Friedman, I. and O'Neil, J. R., 1977. Compilation of stable isotope fractionation factors of geochemical interest. In: M. Fleischer (Editor), Data of Geochemistry, 6th ed., Ch. KK. U. S. Geol. Surv. Prof. Pap. 440-KK, 12 pp. and 49 figs.

Given, R. K. and Wilkinson, B. H., 1985. Kinetic control of morphology, composition, and mineralogy of abiotic sedimentary carbonates. J. Sediment. Petrol., 55: 109-119.

Goldstein, R. H., 1988. Cement stratigraphy of Pennsylvanian Holder Formation, Sacramento Mountains, New Mexico. Am. Assoc. Pet. Geol. Bull., 72: 425-438.

Goldstein, R. H., 1990. Petrographic and geochemical evidence for origin of paleospeleothems, New Mexico: Implications for the application of fluid inclusions to studies of diagenesis. J. Sediment. Petrol., 60: 282-292.

Goldstein, R. H., 1991. Stable isotope signatures associated with palaeosols, Pennsylvanian Holder Formation, New Mexico. Sedimentology, 38: 67-77.

Grover, G., Jr. and Read, J. F., 1983. Paleoaquifer and deep burial related cements defined by regional cathodoluminescent patterns, Middle Ordovician carbonates, Virginia. Am. Assoc. Pet. Geol. Bull., 67: 1275-1303.

Harris, W. H. and Matthews, R. K., 1968. Subaerial diagenesis of carbonate sediments: Efficiency of the solution-reprecipitation process. Science, 160: 77-79.

James, N. P. and Bone, Y., 1989. Petrogenesis of Cenozoic, temperate water calcarenites, south Australia: A model for meteoric/shallow burial diagenesis of shallow water calcite sediments. J. Sediment. Petrol., 59: 191-203.

James, N. P. and Choquette, P. W., 1990. Limestones the meteoric diagenetic environment. In: I. A. McIlreath and D. W. Morrow (Editors), Diagenesis. Geosci. Can. Repr. Ser., 4: 35-74. 
Johnson, W. J. and Goldstein, R. H., 1993. Cambrian sea water preserved as inclusions in marine low-magnesium calcite cement. Nature, 362: 335-337.

Kaufman, J., Cander, H. S., Daniels, L. D., and Meyers, W. J., 1988. Calcite cement stratigraphy and cementation history of the Burlington-Keokuk Formation (Mississippian), Illinois and Missouri. J. Sediment. Petrol., 58: 312-326.

Kimbell, T. N. and Humphrey, J. D., 1994. Geochemistry and crystal morphology of aragonite cements of mixing-zone origin, Barbados, West Indies. J. Sediment. Res., A64: 604-614.

Land, L. S., 1967. Diagenesis of skeletal carbonates. J. Sediment. Petrol., 37: 914-930.

Land, L. S., 1970. Phreatic vs. vadose meteoric diagenesis of limestones: Evidence from a fossil water table. Sedimentology, 14: 175-185.

Land, L. S., 1975. Paleohydrology of ancient dolomites; Geochemical evidence. Am. Assoc. Pet. Geol. Bull., 59: 1602-1625.

Land, L. S., Lund, H. J., and McCullough, M. L., 1989. Dynamic circulation of interstitial seawater in a Jamaican fringing reef. Carbonates Evaporites, 4: 1 -7.

Laudon, L. R. and Bowsher, A. L., 1941. Mississippian formations of Sacramento Mountains, New Mexico. Am. Assoc. Pet. Geol. Bull., 25: 2107-2160.

Leutloff, A. H. and Meyers, W. J., 1984. Regional distribution of microdolomite inclusions in Mississippian echinoderms from southwestern New Mexico. J. Sediment. Petrol., 54: 432-446.

Lohmann, K. C, 1988. Geochemical patterns of meteoric diagenetic systems and their application to studies of paleokarst. In: N. P. James and P. W. Choquette (Editors), Paleokarst. Springer-Verlag, New York, pp. 58-80.

Lohmann, K. C and Meyers, W. J., 1977. Microdolomite inclusions in cloudy prismatic calcites: A proposed criterion for former high magnesium calcites. J. Sediment. Petrol., 47: 1078-1088.

Matthews, R. K., 1968. Carbonate diagenesis: Equilibration of sedimentary mineralogy to the subaerial environment; Coral cap of Barbados, West Indies. J. Sediment. Petrol., 38: 1110-1119.

Meyers, W. J., 1973. Chertification and Carbonate Cementation in the Mississippian Lake Valley Formation, Sacramento Mountains, New Mexico. Ph.D. Thesis, Rice University, Houston, Tex., 353 pp.

Meyers, W. J., 1974. Carbonate cement stratigraphy of the Lake Valley Formation, Mississippian, Sacramento Mountains, New Mexico. J. Sediment. Petrol., 44: 837-861.

Meyers, W. J., 1978. Carbonate cements: their regional distribution and interpretation in Mississippian limestones of southwestern New Mexico. Sedimentology, 25: 371-400.

Meyers, W. J., 1989. Trace element and isotope geochemistry of zoned calcite cements. Lake Valley Formation (Mississippian, New Mexico): Insights from water-rock interaction modeling. Sediment. Geol., 65: 355-370.

Meyers, W. J. and Hill, B. E., 1983. Quantitative studies of compaction in Mississippian skeletal limestones. New Mexico. J. Sediment. Petrol., 53: 231-243.

Meyers, W. J. and James, A. T., 1978. Stable isotopes of cherts and carbonate cements in the Lake Valley Formation (Mississippian), Sacramento Mts, New Mexico. Sedimentology, 25: 105-124.

Meyers, W. J. and Lohmann, K. C, 1985. Isotope geochemistry of regionally extensive calcite cement zones and marine components in Mississippian limestones. New Mexico. In: N. Schneidermann and P. M. Harris (Editors), Carbonate Cements. SEPM (Society for Sedimentary Geology) Spec. Publ., 26: 223-239.

Miller, J., 1986. Facies relationships and diagenesis in Waulsortian mudmounds from the lower Carboniferous of Ireland and N. England. In: J. H. Shroeder and B. H. Purser (Editors), Reef Diagenesis. SpringerVerlag, Berlin, pp. 311-335.

Morse, J. W. and Bender, M. L., 1990. Partition coefficients in calcite: Examination of factors influencing the validity of experimental results and their application to natural systems. Chem. Geol., 82: 265-277.

Morse, J. W. and Mackenzie, F. T., 1990. Geochemistry of Sedimentary Carbonates. Elsevier, Amsterdam, 707 pp.

Niemann, J. C. and Read, J. F., 1988. Regional cementation from unconformity-recharged aquifer and burial fluids, Mississippian Newman Limestone, Kentucky. J. Sediment. Petrol., 58: 688-705.

Paquette, J. and Reeder, R. J., 1995. Relationship between surface structure, growth mechanism, and trace element incorporation in calcite. Geochim. Cosmochim. Acta, 59: 735-749.

Pedone, V. A., Dickson, J. A. D., and Meyers, W. J., 1994. Intracrystalline alteration of low-magnesian calcite cement in the Devonian Pillara Formation, Canning Basin, Western Australia. J. Sediment. Res., A64: 160-173. 
Plummer, L. N., 1975. Mixing of sea water with calcium carbonate ground water. In: E. H. T. Whitten (Editor), Quantitative Studies in the Geological Sciences. Geol. Soc. Am. Mem., 142: 219-236.

Popp, B. N., Anderson, T. F., and Sandberg, P. A., 1986. Brachiopods as indicators of original isotopic compositions in some Paleozoic limestones. Geol. Soc. Am. Bull., 97: 1262-1269.

Pray, L. C., 1958. Fenestrate bryozoan core fades, Mississippian bioherms. Southwestern United States. J. Sediment. Petrol., 28: 261-273.

Pray, L. C., 1961. Geology of the Sacramento Mts. escarpment, Otero Co., New Mexico. N. M. State Bur. Mines Miner. Resour. Bull., 35, 133 pp.

Reeder, R. J. and Grams, J. C., 1987. Sector zoning in calcite cement crystals: implications for trace element distributions in carbonates. Geochim. Cosmochim. Acta, 51: 187-194.

Romanek, C. S., Grossman, E. L., and Morse, J. W., 1992. Carbon isotopic fractionation in synthetic aragonite and calcite: Effects of temperature and precipitation rate. Geochim. Cosmochim. Acta, 56: 419-430.

Runnels, D. D., 1969. Diagenesis, chemical sediments, and the mixing of natural waters. J. Sediment. Petrol., 39: 1188-1201.

Sokal, R. R. and Rohlf, F. J., 1969. Biometry: The Principles and Practice of Statistics in Biological Research. W. H. Freeman and Co., San Francisco, Calif., 776 pp.
Steinen, R. P. and Matthews, R. K., 1973. Phreatic vs. vadose diagenesis: Stratigraphy and mineralogy of a cored bore hole on Barbados, W. I. J. Sediment. Petrol., 43: 1012-1020.

Vail, P. R. and Mitchum, R. M., 1975. Eustatic cycles from seismic data for global stratigraphic analysis, reviewed by W. C. Gussow. In: Sequence concepts in petroleum engineering. Geotimes, 21: 16-17.

Veizer, J., Fritz, P., and Jones, B., 1986. Geochemistry of brachiopods, oxygen and carbon isotopic records of Paleozoic oceans. Geochim. Cosmochim. Acta, 50: 1679-1696.

Wagner, P. D. and Matthews, R. K., 1982. Porosity preservation in the upper Smackover (Jurassic) carbonate grainstone, Walker Creek field, Arkansas: Response of paleophreatic lenses to burial processes. J. Sediment. Petrol., 52: 3-18.

Wigley, T. M. L. and Plummer, L. N., 1976. Mixing of carbonate waters. Geochim. Cosmochim. Acta, 40: 989-995.

Wilkinson, B. H., 1979. Biomineralization, paleoceanography, and the evolution of calcareous marine organisms. Geology, 7: 524-527.

Wilkinson, B. H., Janecke, S. U., and Brett, C. E., 1982. Lownesian calcite marine cement in Middle Ordovician hardgrounds from Kirkfield, Ontario. J. Sediment. Petrol., 52: 47-57. 